flSupporting Information

\title{
Systematic Modifications of a Simple Tolan: Another Category of Viscosity Sensor
}

Jung-Ho Hong, Min-Sung Ko, P. Sankara Rao, and Dong-Gyu Cho*

dgcho@inha.ac.kr

Department of Chemistry and Chemical Engineering, Inha University, Incheon, 22212, Republic of Korea

\section{Contents}

General experimental and synthetic details

S2

2D NMR spectra of 5d, $5 \mathrm{~d}$, and $5 e$

S5

Spectroscopic studies

S8

Properties of $5 \mathrm{~d}$ as a viscosity sensor

S17

NMR Spectra of tolan derivatives

S18 


\section{General experimental and Synthetic details}

Reagents were purchased at the highest commercial quality and used without further purification, unless otherwise stated. Yields of synthesized compounds were measured after chromatographic purification. ${ }^{1} \mathrm{H}$, ${ }^{13} \mathrm{C}$, and 2D-NMR spectra were measured at $25^{\circ} \mathrm{C}$ using $400 \mathrm{MHz}$ spectrometers. HRMS were recorded by EI methods using a magnetic sector-electric sector double focusing analyzer.

\section{General Synthetic procedure}

\section{1-(phenylethynyl)naphthalene (3a)}

Iodobenzene $(0.246 \mathrm{~g}, 1.206 \mathrm{mmol})$ was added to the solution of 1-ethynylnaphthalene $(0.202 \mathrm{~g}, 1.326$ $\mathrm{mmol}$ ) in a mixture of $6.0 \mathrm{~mL}$ of anhydrous DMF and $6.0 \mathrm{~mL}$ of triethylamine. The resulting mixture was degassed for $5 \mathrm{~min}$ and then $\mathrm{Pd}\left(\mathrm{PPh}_{3}\right)_{2} \mathrm{Cl}_{2}(0.042 \mathrm{~g}, 0.060 \mathrm{mmol})$ and $\mathrm{CuI}(0.012 \mathrm{~g}, 0.060 \mathrm{mmol})$ were added to the solution under Ar. The resulting mixture was heated at $80^{\circ} \mathrm{C}$ for $2 \mathrm{~h}$. After cooling the reaction to room temperature, the reaction mixture was poured into water and extracted with DCM. The organic layer was dried over anhydrous $\mathrm{Na}_{2} \mathrm{SO}_{4}$ and evaporated to dryness. The residue was purified over silica gel (eluent: n-Hexane) to afford the compound (92 mg, 33.1\%). ${ }^{1} \mathrm{H}$ NMR (400 MHz, Chloroform- $d$ ) $\delta 8.45$ $(\mathrm{d}, J=8.3 \mathrm{~Hz}, 1 \mathrm{H}), 7.86(\mathrm{dd}, J=8.3,8.3 \mathrm{~Hz}, 2 \mathrm{H}), 7.76(\mathrm{dd}, J=7.2,1.2 \mathrm{~Hz}, 1 \mathrm{H}), 7.68-7.63(\mathrm{~m}, 2 \mathrm{H}), 7.60$ (ddd, $J=8.3,6.8,1.4 \mathrm{~Hz}, 1 \mathrm{H}), 7.53(\mathrm{ddd}, J=8.1,6.8,1.3 \mathrm{~Hz}, 1 \mathrm{H}), 7.46$ (dd, $J=8.3,7.2 \mathrm{~Hz}, 1 \mathrm{H}$ ), $7.43-$ $7.35(\mathrm{~m}, 3 \mathrm{H}) ;{ }^{13} \mathrm{C} \mathrm{NMR}(100 \mathrm{MHz}$, Chloroform- $d$ ) $\delta 133.4,133.3,131.8,130.5,128.8,128.5$ (two signals),

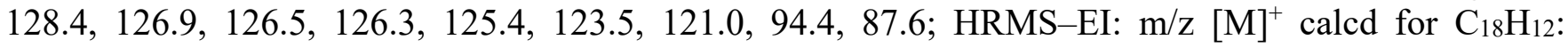
228.0939; found: 228.0941 .

\section{8-(phenylethynyl)quinoline (3b)}

Iodobenzene $(0.207 \mathrm{~g}, 1.014 \mathrm{mmol})$ was added to the solution of 8-ethynylquinoline $(0.171 \mathrm{~g}, 1.116 \mathrm{mmol})$ in a mixture of $5.1 \mathrm{~mL}$ of anhydrous DMF and $5.1 \mathrm{~mL}$ of triethylamine. The resulting mixture was degassed for $5 \mathrm{~min}$ and then $\mathrm{Pd}\left(\mathrm{PPh}_{3}\right)_{2} \mathrm{Cl}_{2}(0.036 \mathrm{~g}, 0.051 \mathrm{mmol})$ and $\mathrm{CuI}(0.009 \mathrm{~g}, 0.051 \mathrm{mmol})$ were added to the solution under Ar. The resulting mixture was heated at $80^{\circ} \mathrm{C}$ for $4 \mathrm{~h}$. After cooling the reaction to room temperature, the reaction mixture was poured into water and extracted with DCM. The organic layer was dried over anhydrous $\mathrm{Na}_{2} \mathrm{SO}_{4}$ and evaporated to dryness. The residue was purified over silica gel (Ethyl Acetate:Hexane $=1: 2)$ to afford the compound $(54 \mathrm{mg}, 23.3 \%)$. ${ }^{1} \mathrm{H}$ NMR $(400 \mathrm{MHz}$, Chloroform- $d$ ) $\delta 8.92(\mathrm{dd}, J=4.2,1.8 \mathrm{~Hz}, 1 \mathrm{H}), 8.03(\mathrm{dd}, J=8.3,1.8 \mathrm{~Hz}, 1 \mathrm{H}), 7.86(\mathrm{dd}, J=7.2,1.4 \mathrm{~Hz}$, $1 \mathrm{H}), 7.67(\mathrm{dd}, J=8.2,1.4 \mathrm{~Hz}, 1 \mathrm{H}), 7.59-7.48(\mathrm{~m}, 2 \mathrm{H}), 7.39(\mathrm{dd}, J=8.2,7.2 \mathrm{~Hz}, 1 \mathrm{H}), 7.31(\mathrm{dd}, J=8.3$, $4.2 \mathrm{~Hz}, 1 \mathrm{H}), 7.27-7.15(\mathrm{~m}, 3 \mathrm{H}) ;{ }^{13} \mathrm{C}$ NMR $(100 \mathrm{MHz}$, Chloroform- $d) \delta 151.2,148.2,136.6,134.3,132.1$, $128.5,128.3,126.2,123.6,121.7,95.5,87.3$ (three peaks are overlapped); HRMS-EI: $\mathrm{m} / \mathrm{z}$ [M] ${ }^{+}$calcd for $\mathrm{C}_{17} \mathrm{H}_{11} \mathrm{~N}: 229.0891$; found: 229.0890 .

\section{methyl 2-(naphthalen-1-ylethynyl)benzoate (3c)}

Methyl 2-iodobenzoate $(0.316 \mathrm{~g}, 1.206 \mathrm{mmol})$ was added to the solution of 1-ethynylnaphthalene $(0.202$ $\mathrm{g}, 1.326 \mathrm{mmol}$ ) in a mixture of $6.0 \mathrm{~mL}$ of anhydrous DMF and $6.0 \mathrm{~mL}$ of triethylamine. The resulting mixture was degassed for $5 \mathrm{~min}$ and then $\mathrm{Pd}\left(\mathrm{PPh}_{3}\right)_{2} \mathrm{Cl}_{2}(0.042 \mathrm{~g}, 0.060 \mathrm{mmol})$ and $\mathrm{CuI}(0.012 \mathrm{~g}, 0.060$ mmol) were added to the solution under Ar. The resulting mixture was heated at $80{ }^{\circ} \mathrm{C}$ for $5 \mathrm{~h}$. After cooling the reaction to room temperature, the reaction mixture was poured into water and extracted with DCM. The organic layer was dried over anhydrous $\mathrm{Na}_{2} \mathrm{SO}_{4}$ and evaporated to dryness. The residue was purified over silica gel (Ethyl Acetate:Hexane =1:9) to afford the compound $(218 \mathrm{mg}, 63.2 \%) .{ }^{1} \mathrm{H}$ NMR $(400 \mathrm{MHz}$, Chloroform- $d$ ) $\delta 8.59(\mathrm{~d}, J=8.3 \mathrm{~Hz}, 1 \mathrm{H}), 8.02(\mathrm{ddd}, J=7.8,1.4,0.5 \mathrm{~Hz}, 1 \mathrm{H}), 7.86(\mathrm{~m}, 2 \mathrm{H})$, $7.80(\mathrm{dd}, J=7.1,1.2 \mathrm{~Hz}, 1 \mathrm{H}), 7.77$ (ddd, $J=7.8,1.3,0.6 \mathrm{~Hz}, 1 \mathrm{H}), 7.61$ (ddd, $J=8.3,6.8,1.4 \mathrm{~Hz}, 1 \mathrm{H}$ ), $7.54(\mathrm{~m}, 2 \mathrm{H}), 7.46(\mathrm{dd}, J=8.3,7.2 \mathrm{~Hz}, 1 \mathrm{H}), 7.41(\mathrm{ddd}, J=7.9,7.4,1.3 \mathrm{~Hz}, 1 \mathrm{H}), 3.99(\mathrm{~s}, 3 \mathrm{H}) ;{ }^{13} \mathrm{C}$ NMR $(100 \mathrm{MHz}$, Chloroform- $d$ ) $\delta 166.9,134.4,133.6,133.3,131.9,131.8,130.9,130.7,129.2,128.3,128.1$, 127.0, 126.6(two signals), 125.4, 123.9, 121.2, 93.1, 92.8, 52.4; HRMS-EI: $\mathrm{m} / \mathrm{z}[\mathrm{M}]^{+}$calcd for $\mathrm{C}_{20} \mathrm{H}_{14} \mathrm{O}_{2}$ : 286.0994; found: 286.0997. 


\section{2-(naphthalen-1-ylethynyl)benzoic acid (4c)}

$\mathrm{NaOH}(2.150 \mathrm{~g}, 53.750 \mathrm{mmol})$ was added to a solution of compound $\mathbf{3 c}(0.290 \mathrm{~g}, 1.010 \mathrm{mmol})$ in the mixed solvent $\left(20 \mathrm{~mL}\right.$ of $\mathrm{MeOH}, 50 \mathrm{~mL}$ of THF, and $80 \mathrm{~mL}$ of $\left.\mathrm{H}_{2} \mathrm{O}\right)$ at room temperature. The mixture was stirred for $14 \mathrm{~h}$ at the same temperature. The reaction mixture was washed with DCM and acidfied with $10 \%$ aqueous $\mathrm{HCl}$. The aqueous layer was extracted with EtOAc. The organic layer was dried over anhydrous $\mathrm{Na}_{2} \mathrm{SO}_{4}$ and evaporated to dryness. The residue was purified over silica gel (Ethyl Acetate:Hexane $=1: 1)$ to afford the compound $(230 \mathrm{mg}, 82.7 \%) .{ }^{1} \mathrm{H}$ NMR (400 MHz, Acetone- $\left.d_{6}\right) \delta 8.72$ $(\mathrm{d}, J=8.3 \mathrm{~Hz}, 1 \mathrm{H}), 8.07(\mathrm{ddd}, J=7.9,1.5,0.6 \mathrm{~Hz}, 1 \mathrm{H}), 7.98-7.91(\mathrm{~m}, 2 \mathrm{H}), 7.86-7.78(\mathrm{~m}, 2 \mathrm{H}), 7.68-$ $7.55(\mathrm{~m}, 3 \mathrm{H}), 7.55-7.49(\mathrm{~m}, 2 \mathrm{H}) ;{ }^{13} \mathrm{C}$ NMR $(100 \mathrm{MHz}$, Acetone-d6) $\delta 166.5,134.3,133.6,133.5,132.3$, $132.0,130.8,130.7,129.2,128.4,128.3,127.0,126.7,125.5,123.8,121.1,93.2,92.4$ (one carbon signal is overlapped); HRMS-EI: m/z [M] ${ }^{+}$calcd for $\mathrm{C}_{19} \mathrm{H}_{12} \mathrm{O}_{2}: 272.0837$; found: 272.0839

\section{(Z)-3-(naphthalen-1-ylmethylene)isobenzofuran-1(3H)-one (5c)}

A mixture of 2-(naphthalen-1-ylethynyl)benzoic acid (300 mg, $1.170 \mathrm{mmol}),\left(\mathrm{PPh}_{3}\right)_{2} \mathrm{PdCl}_{2}(36 \mathrm{mg}, 0.054$ $\mathrm{mmol})$ and $\mathrm{CuI}(9.0 \mathrm{mg}, 0.054 \mathrm{mmol})$ in DMF $(30 \mathrm{ml})$ was purged with Ar for $10 \mathrm{~min}$. Triethylamine $(0.780 \mathrm{~mL}, 5.40 \mathrm{mmol})$ was added and the mixture was stirred for $6 \mathrm{~h}$ at $80^{\circ} \mathrm{C}$. The mixture was cooled to room temperature and brine solution was added. The solution was extracted with EtOAc. The organic layer was dried over anhydrous $\mathrm{Na}_{2} \mathrm{SO}_{4}$ and evaporated to dryness. The residue was purified over silica gel (Ethyl Acetate:Hexane = 1:9) to give the cyclized product $(210 \mathrm{mg}, 70.0 \%) .{ }^{1} \mathrm{H}$ NMR $(400 \mathrm{MHz}$, Chloroform- $d) \delta 8.31(\mathrm{~d}, J=7.4 \mathrm{~Hz}, 1 \mathrm{H}), 8.19(\mathrm{~d}, J=8.4 \mathrm{~Hz}, 1 \mathrm{H}), 7.97(\mathrm{dd}, J=7.7 \mathrm{~Hz}, 1 \mathrm{H}), 7.93(\mathrm{~d}, J=$ $7.9 \mathrm{~Hz}, 1 \mathrm{H}), 7.89(\mathrm{~d}, J=8.2 \mathrm{~Hz}, 1 \mathrm{H}), 7.84(\mathrm{~d}, J=8.2 \mathrm{~Hz}, 1 \mathrm{H}), 7.78(\mathrm{t}, J=7.6 \mathrm{~Hz}, 1 \mathrm{H}), 7.63-7.45(\mathrm{~m}$, 4H), $7.21(\mathrm{~s}, 1 \mathrm{H}) ;{ }^{13} \mathrm{C}$ NMR $(100 \mathrm{MHz}$, Chloroform- $d) \delta 167.3,145.8,140.6,134.6,133.8,131.6,130.1$, 129.5, 129.1 (two signals), 128.9, 126.6, 125.9 (two signals), 125.7, 123.8, 123.3, 120.1, 103.1; $v_{\max }(\mathrm{KBr}) / \mathrm{cm}^{-1} 1769,1757$; HRMS-EI: $\mathrm{m} / \mathrm{z}[\mathrm{M}]^{+}$calcd for $\mathrm{C}_{19} \mathrm{H}_{12} \mathrm{O}_{2}: 272.0837$; found: 272.0838

\section{methyl 2-(quinolin-8-ylethynyl)benzoate (3d)}

Methyl 2-iodobenzoate $(0.400 \mathrm{~g}, 1.526 \mathrm{mmol})$ was added to the solution of 8-ethynylquinoline $(0.281 \mathrm{~g}$, $1.832 \mathrm{mmol}$ ) in $7.6 \mathrm{~mL}$ of triethylamine. The resulting mixture was degassed for 5 min and then $\mathrm{Pd}\left(\mathrm{PPh}_{3}\right)_{2} \mathrm{Cl}_{2}(0.032 \mathrm{~g}, 0.046 \mathrm{mmol})$ and $\mathrm{CuI}(0.009 \mathrm{~g}, 0.046 \mathrm{mmol})$ were added to the solution under Ar. The resulting mixture was heated at $80{ }^{\circ} \mathrm{C}$ for $3 \mathrm{~h}$. After cooling the reaction to room temperature, the reaction mixture was evaporated to dryness. The residue was purified over silica gel (Ethyl Acetate:Hexane $=1: 2$ ) to afford the compound (204 mg, 46.4\%). ${ }^{1} \mathrm{H}$ NMR (400 MHz, Chloroform- $d$ ) $\delta 9.05$ (dd, $J=4.3$, $1.7 \mathrm{~Hz}, 1 \mathrm{H}), 8.16(\mathrm{ddd}, J=8.3,1.8,0.5 \mathrm{~Hz}, 1 \mathrm{H}), 8.05(\mathrm{dd}, J=7.2,1.4 \mathrm{~Hz}, 1 \mathrm{H}), 8.00$ (ddd, $J=7.9,1.4$, $0.6 \mathrm{~Hz}, 1 \mathrm{H}), 7.87-7.77(\mathrm{~m}, 2 \mathrm{H}), 7.56-7.47(\mathrm{~m}, 2 \mathrm{H}), 7.44(\mathrm{dd}, J=8.3,4.2 \mathrm{~Hz}, 1 \mathrm{H}), 7.42-7.35(\mathrm{~m}, 1 \mathrm{H})$, 3.99 (s, 3H); ${ }^{13} \mathrm{C}$ NMR $(100 \mathrm{MHz}$, Chloroform- $d$ ) $\delta 167.0,151.1,148.3,136.5,134.6,134.5,132.1,131.7$, $130.5,128.7,128.4,128.1,126.2,124.1,123.7,121.7,94.2,92.3,52.4 ;$ HRMS-EI: $\mathrm{m} / \mathrm{z}[\mathrm{M}]^{+}$calcd for $\mathrm{C}_{19} \mathrm{H}_{13} \mathrm{NO}_{2}: 287.0946$; found: 287.0945 .

\section{(Z)-3-(quinolin-8-ylmethylene)isobenzofuran-1(3H)-one (5d)}

$\mathrm{NaOH}(2.400 \mathrm{~g}, 60.0 \mathrm{mmol})$ was added to a solution of compound $\mathbf{3 d}(0.345 \mathrm{~g}, 1.200 \mathrm{mmol})$ in the mixed solvent $\left(75 \mathrm{~mL}\right.$ of $\mathrm{MeOH}$ and $35 \mathrm{~mL}$ of $\left.\mathrm{H}_{2} \mathrm{O}\right)$ at room temperature. The mixture was stirred for $24 \mathrm{~h}$ at the same temperature. The reaction mixture was washed with DCM and the aqueous layer was neutralized $(\mathrm{pH}=6)$ with $10 \%$ aqueous $\mathrm{HCl}$. The aqueous layer was extracted with DCM. The organic layer was dried over anhydrous $\mathrm{Na}_{2} \mathrm{SO}_{4}$ and evaporated to dryness. The residue was purified over silica gel (Ethyl Acetate:Hexane $=1: 2)$ to afford the compound $(270 \mathrm{mg}, 81.6 \%) .{ }^{1} \mathrm{H}$ NMR $(400 \mathrm{MHz}$, Chloroform-d) $\delta$ $8.97(\mathrm{dd}, J=4.2,1.8 \mathrm{~Hz}, 1 \mathrm{H}), 8.75(\mathrm{dd}, J=7.5,1.4 \mathrm{~Hz}, 1 \mathrm{H}), 8.17(\mathrm{dd}, J=8.2,1.8 \mathrm{~Hz}, 1 \mathrm{H}), 8.11(\mathrm{~s}, 1 \mathrm{H})$, $8.03(\mathrm{dt}, J=7.8,0.9 \mathrm{~Hz}, 1 \mathrm{H}), 7.95(\mathrm{dt}, J=7.7,1.0 \mathrm{~Hz}, 1 \mathrm{H}), 7.79(\mathrm{dd}, J=8.2,1.4 \mathrm{~Hz}, 1 \mathrm{H}), 7.77-7.72(\mathrm{~m}$, $1 \mathrm{H}), 7.64(\mathrm{t}, J=7.8 \mathrm{~Hz}, 1 \mathrm{H}), 7.55(\mathrm{td}, J=7.5,0.9 \mathrm{~Hz}, 1 \mathrm{H}), 7.45(\mathrm{dd}, J=8.2,4.2 \mathrm{~Hz}, 1 \mathrm{H}) ;{ }^{13} \mathrm{C}$ NMR $(100$ MHz, Chloroform- $d$ ) $\delta 167.5,149.6,145.9,141.1,136.9,134.6,131.8,131.2,129.9,128.5,128.2,127.0$, 125.5, 123.6, 121.4, 120.8, 102.1 (one carbon signal is overlapped); $v_{\max }(\mathrm{KBr}) / \mathrm{cm}^{-1} 1770 ; \mathrm{HRMS}-\mathrm{EI}: \mathrm{m} / \mathrm{z}$ $[\mathrm{M}]^{+}$calcd for $\mathrm{C}_{18} \mathrm{H}_{11} \mathrm{NO}_{2}$ : 273.0790; found: 273.0788 . 


\section{methyl 2-(anthracen-9-ylethynyl)benzoate (3e)}

Methyl 2-ethynylbenzoate $(0.200 \mathrm{~g}, 1.25 \mathrm{mmol})$ was added to the solution of 9-bromoanthracene $(0.292$ $\mathrm{g}, 1.14 \mathrm{mmol}$ ) in a mixture of $5.7 \mathrm{~mL}$ of anhydrous DMF and $5.7 \mathrm{~mL}$ of triethylamine. The resulting mixture was degassed for $5 \mathrm{~min}$ and then $\mathrm{Pd}\left(\mathrm{PPh}_{3}\right)_{2} \mathrm{Cl}_{2}(0.040 \mathrm{~g}, 0.057 \mathrm{mmol})$ and $\mathrm{CuI}(0.011 \mathrm{~g}, 0.057$ mmol) were added to the solution under Ar. The resulting mixture was heated at $80{ }^{\circ} \mathrm{C}$ for $12 \mathrm{~h}$. After cooling the reaction to room temperature, the reaction mixture was poured into water and extracted with DCM. The organic layer was dried over anhydrous $\mathrm{Na}_{2} \mathrm{SO}_{4}$ and evaporated to dryness. The residue was purified over silica gel (Dichloromethane:Hexane $=1: 1)$ to afford the compound $(178 \mathrm{mg}, 46.5 \%) .{ }^{1} \mathrm{H}$ NMR (400 MHz, Chloroform-d) $\delta 8.80$ (dd, $J=8.7,1.0 \mathrm{~Hz}, 2 \mathrm{H}), 8.45$ (s, 1H), 8.07 (ddd, $J=7.9,1.5,0.6$ $\mathrm{Hz}, 1 \mathrm{H}), 8.02$ (ddt, $J=8.3,1.2,0.7 \mathrm{~Hz}, 2 \mathrm{H}), 7.92$ (ddd, $J=7.8,1.4,0.6 \mathrm{~Hz}, 1 \mathrm{H}), 7.65-7.55(\mathrm{~m}, 3 \mathrm{H}), 7.52$ (ddd, $J=8.5,6.6,1.3 \mathrm{~Hz}, 2 \mathrm{H}), 7.45$ (ddd, $J=7.9,7.5,1.3 \mathrm{~Hz}, 1 \mathrm{H}), 4.03(\mathrm{~s}, 3 \mathrm{H}) ;{ }^{13} \mathrm{C}$ NMR $(100 \mathrm{MHz}$, Chloroform- $d$ ) $\delta 167.0,134.5,133.1,131.9,131.6,131.3,130.9,128.7,128.2,128.1,127.0,126.8,125.8$, 124.1, 117.4, 99.6, 91.6, 52.5; HRMS-EI: $\mathrm{m} / \mathrm{z}[\mathrm{M}]^{+}$calcd for $\mathrm{C}_{24} \mathrm{H}_{16} \mathrm{O}_{2}: 336.1150$; found: 336.1152 .

\section{2-(anthracen-9-ylethynyl)benzoic acid (4e)}

$\mathrm{NaOH}(1.200 \mathrm{~g}, 29.8 \mathrm{mmol})$ was added to a solution of compound $3 \mathbf{e}(0.400 \mathrm{~g}, 1.190 \mathrm{mmol})$ in the mixed solvent $\left(48 \mathrm{~mL}\right.$ of $\mathrm{MeOH}, 24 \mathrm{~mL}$ of $\mathrm{THF}$, and $24 \mathrm{~mL}$ of $\left.\mathrm{H}_{2} \mathrm{O}\right)$ at room temperature. The mixture was stirred for $24 \mathrm{~h}$ at the same temperature. The reaction mixture was washed with DCM and acidfied with $10 \%$ aqueous $\mathrm{HCl}$. The aqueous layer was extracted with DCM. The organic layer was dried over anhydrous $\mathrm{Na}_{2} \mathrm{SO}_{4}$ and evaporated to dryness. The residue was purified over silica gel (Ethyl Acetate:Hexane $=1: 1)$ to afford the compound $(380 \mathrm{mg}, 100 \%) .{ }^{1} \mathrm{H}$ NMR $(400 \mathrm{MHz}$, Acetone- $d 6) \delta 8.92$ $(\mathrm{dd}, J=8.7,1.1 \mathrm{~Hz}, 2 \mathrm{H}), 8.61(\mathrm{~s}, 1 \mathrm{H}), 8.14(\mathrm{ddd}, J=7.9,1.4,0.6 \mathrm{~Hz}, 1 \mathrm{H}), 8.13-8.08(\mathrm{~m}, 2 \mathrm{H}), 8.05$ (ddd, $J=7.8,1.3,0.6 \mathrm{~Hz}, 1 \mathrm{H}), 7.71(\mathrm{td}, J=7.6,1.4 \mathrm{~Hz}, 1 \mathrm{H}), 7.64(\mathrm{ddd}, J=8.7,6.6,1.3 \mathrm{~Hz}, 2 \mathrm{H}), 7.60-7.52$ $(\mathrm{m}, 3 \mathrm{H}) ;{ }^{13} \mathrm{C}$ NMR $\left(100 \mathrm{MHz}\right.$, Acetone- $\left.d_{6}\right) \delta 166.6,134.5,133.1,132.2,131.8,131.4,130.9,128.8,128.5$, 128.4, 127.1, 127.0, 126.0, 124.0, 117.2, 99.9, 91.2; HRMS-EI: $\mathrm{m} / \mathrm{z}[\mathrm{M}]^{+}$calcd for $\mathrm{C}_{23} \mathrm{H}_{14} \mathrm{O}_{2}: 322.0994$; found: 322.0996

\section{3-(anthracen-9-yl)-1H-isochromen-1-one (5e)}

A mixture of 2-(anthracen-9-ylethynyl)benzoic acid (350 mg, $1.050 \mathrm{mmol}),\left(\mathrm{PPh}_{3}\right)_{2} \mathrm{PdCl}_{2}(35.0 \mathrm{mg}, 0.050$ $\mathrm{mmol})$ and $\mathrm{CuI}(10.0 \mathrm{mg}, 0.050 \mathrm{mmol})$ in DMF $(50 \mathrm{~mL})$ was purged with Ar for $10 \mathrm{~min}$. Triethylamine $(0.750 \mathrm{~mL}, 5.0 \mathrm{mmol})$ was added and the mixture was stirred for $1 \mathrm{~h}$ at $80{ }^{\circ} \mathrm{C}$. The mixture was cooled to room temperature and brine solution was added. The resulted solution was extracted with EtOAc. The organic layer was dried over anhydrous $\mathrm{Na}_{2} \mathrm{SO}_{4}$ and evaporated to dryness. The residue was purified over silica gel (Hexane: DCM $=4: 6)$ to afford the compound $(250 \mathrm{mg}, 71.4 \%) .{ }^{1} \mathrm{H}$ NMR $(400 \mathrm{MHz}$, Chloroform- $d$ ) $\delta 8.59(\mathrm{~s}, 1 \mathrm{H}), 8.45(\mathrm{~d}, J=8.0 \mathrm{~Hz}, 1 \mathrm{H}), 8.08-8.00(\mathrm{~m}, 4 \mathrm{H}), 7.82(\mathrm{~d}, J=7.9 \mathrm{~Hz}, 1 \mathrm{H}), 7.63$ $(\mathrm{d}, J=8.0 \mathrm{~Hz}, 1 \mathrm{H}), 7.56(\mathrm{~d}, J=7.9,1 \mathrm{H}), 7.52-7.43(\mathrm{~m}, 4 \mathrm{H}), 6.81(\mathrm{~s}, 1 \mathrm{H}) ;{ }^{13} \mathrm{C}$ NMR $(100 \mathrm{MHz}$, Chloroform-d) $\delta 163.1,152.5,137.2,135.2,131.2,130.7,130.0,129.7,128.8,128.7,126.9,126.8,126.0$, 125.5(two signals), $120.9,110.0 ; \nu_{\max }(\mathrm{KBr}) / \mathrm{cm}^{-1} 1720 ; \mathrm{HRMS}-\mathrm{EI}: \mathrm{m} / \mathrm{z}[\mathrm{M}]^{+}$calcd for $\mathrm{C}_{23} \mathrm{H}_{14} \mathrm{O}_{2}$ : 322.0994; found: 322.0996 
2D NMR spectra

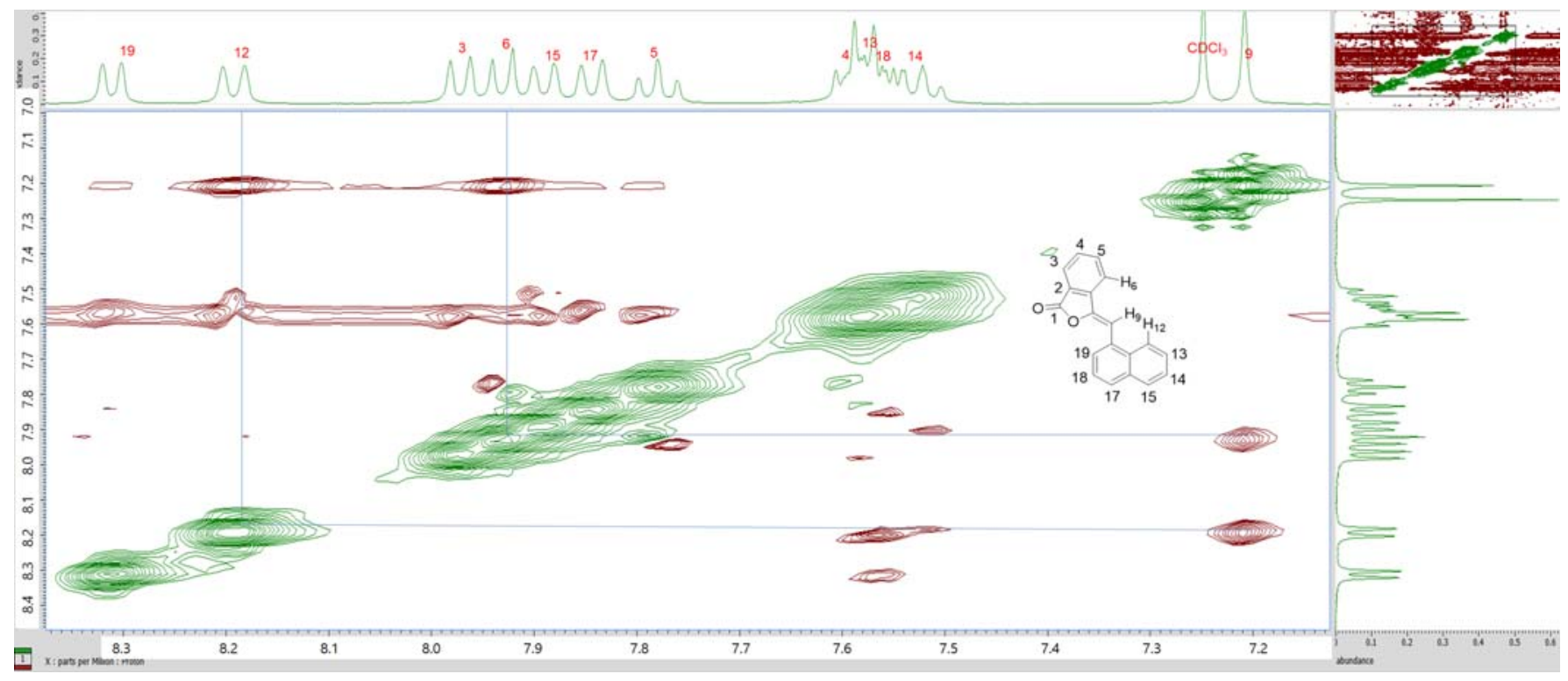

Figure S1. 2D NOESY spectrum of $\mathbf{5 c}$ in $\mathrm{CDCl}_{3}$ at $25^{\circ} \mathrm{C}(400 \mathrm{MHz})$

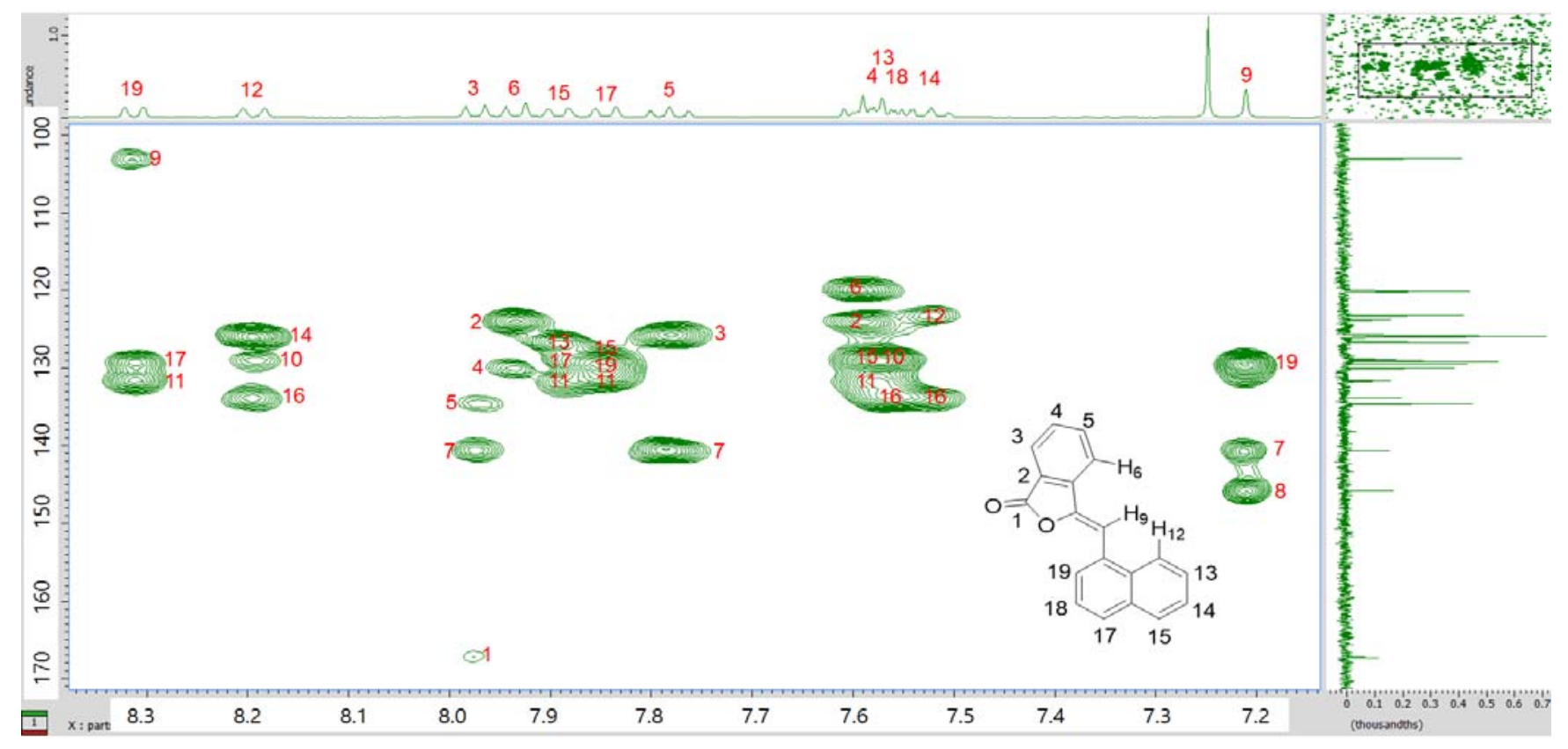

Figure S2. 2D HMBC spectrum of $\mathbf{5 c}$ in $\mathrm{CDCl}_{3}$ at $25{ }^{\circ} \mathrm{C}(400 \mathrm{MHz})$ 


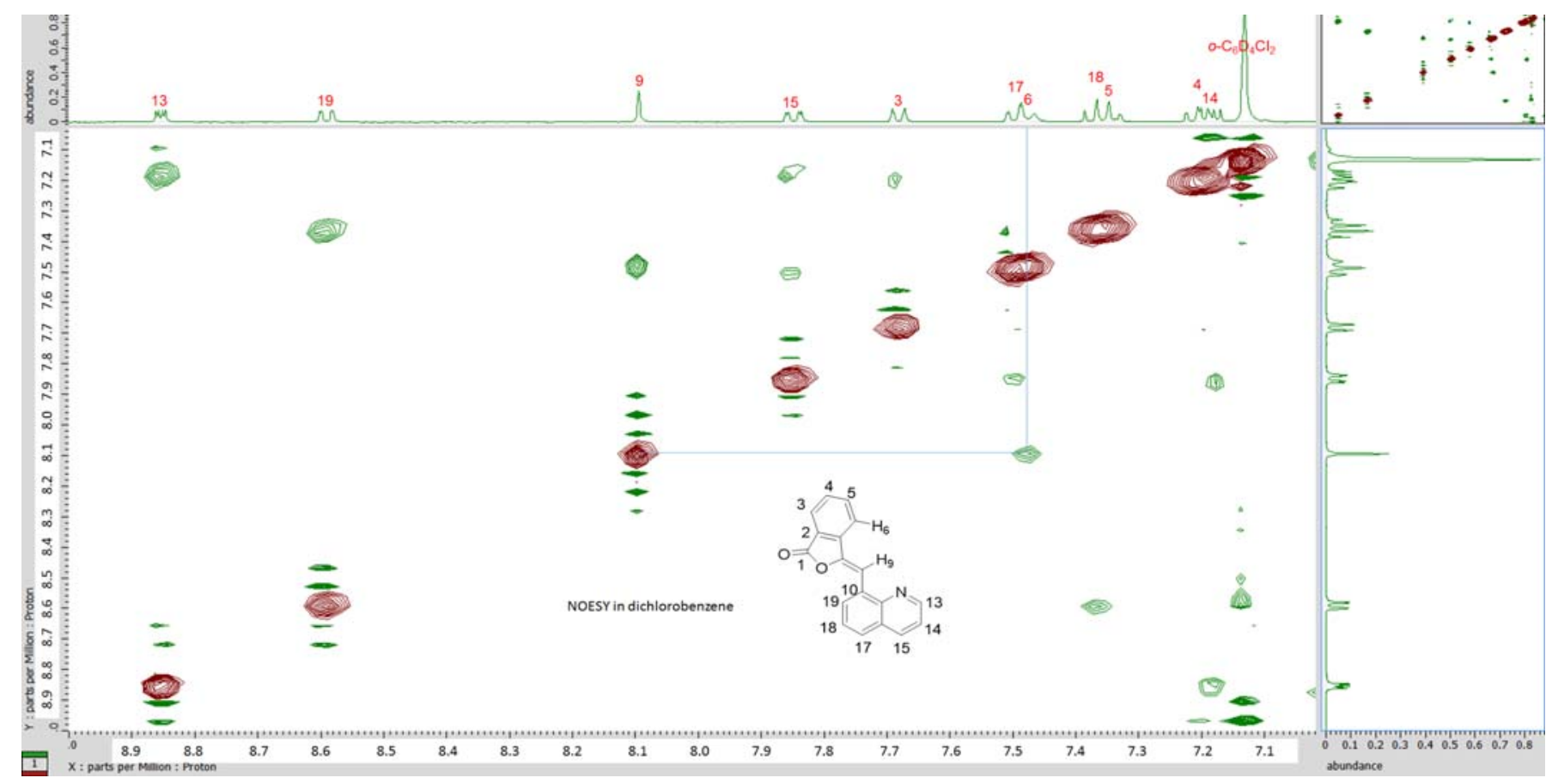

Figure S3. 2D NOESY spectrum of $5 \mathbf{d}$ in dichlorobenzene- $d_{4}$ at $25^{\circ} \mathrm{C}(400 \mathrm{MHz})$

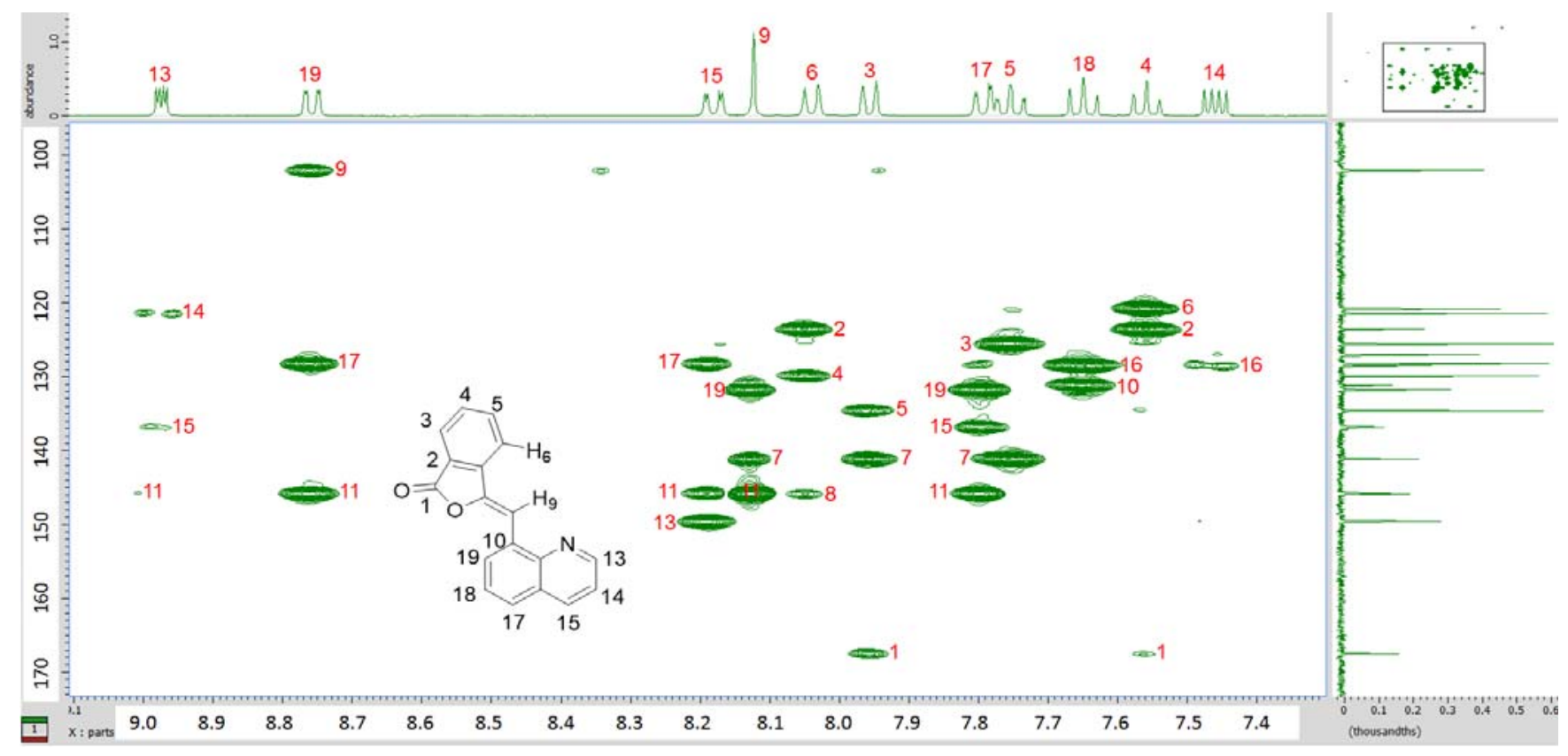

Figure S4. 2D HMBC spectrum of $\mathbf{5 d}$ in $\mathrm{CDCl}_{3}$ at $25{ }^{\circ} \mathrm{C}(400 \mathrm{MHz})$ 


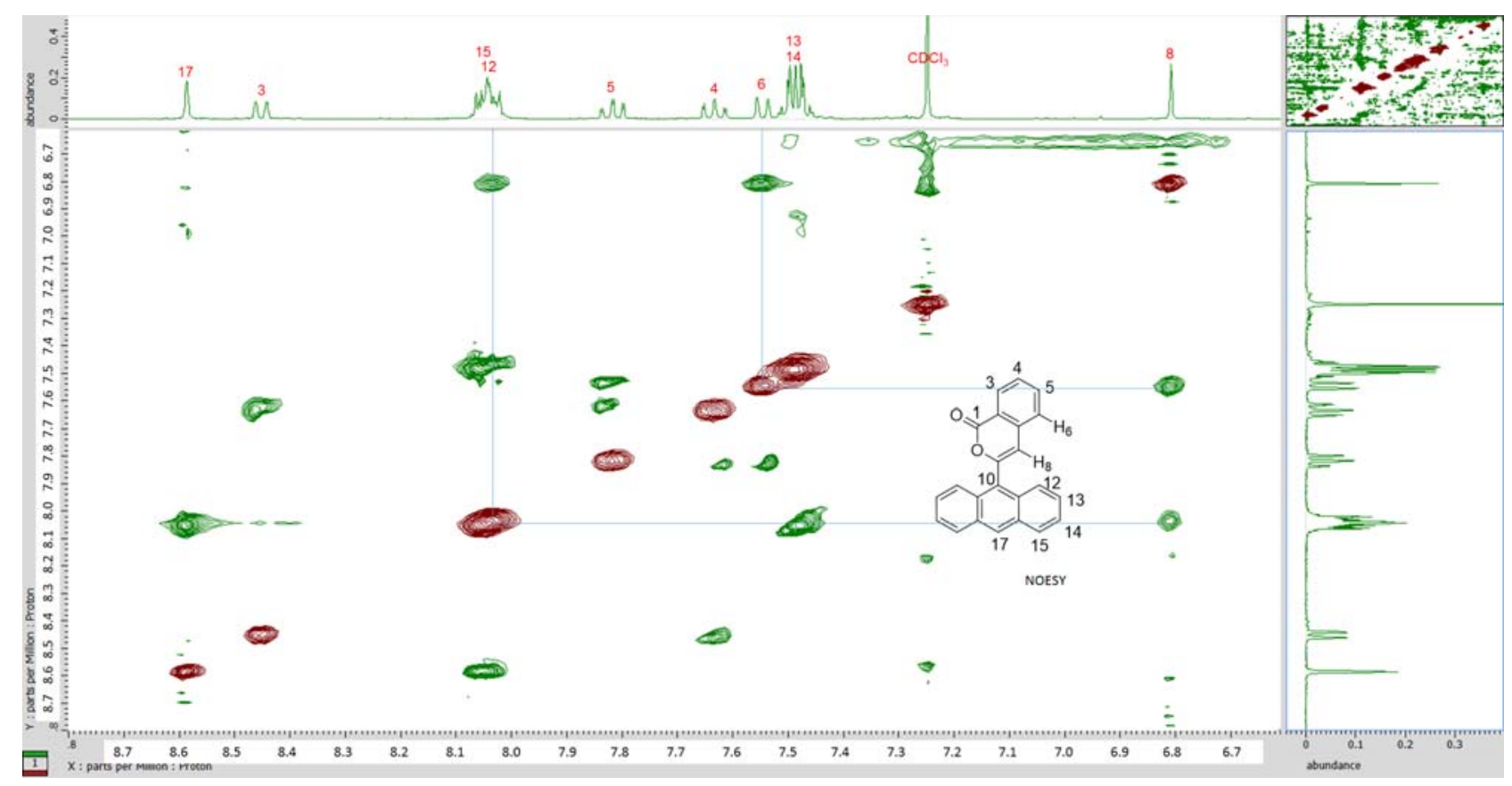

Figure S5. 2D NOESY spectrum of $5 \mathbf{e}$ in $\mathrm{CDCl}_{3}$ at $25^{\circ} \mathrm{C}(400 \mathrm{MHz})$

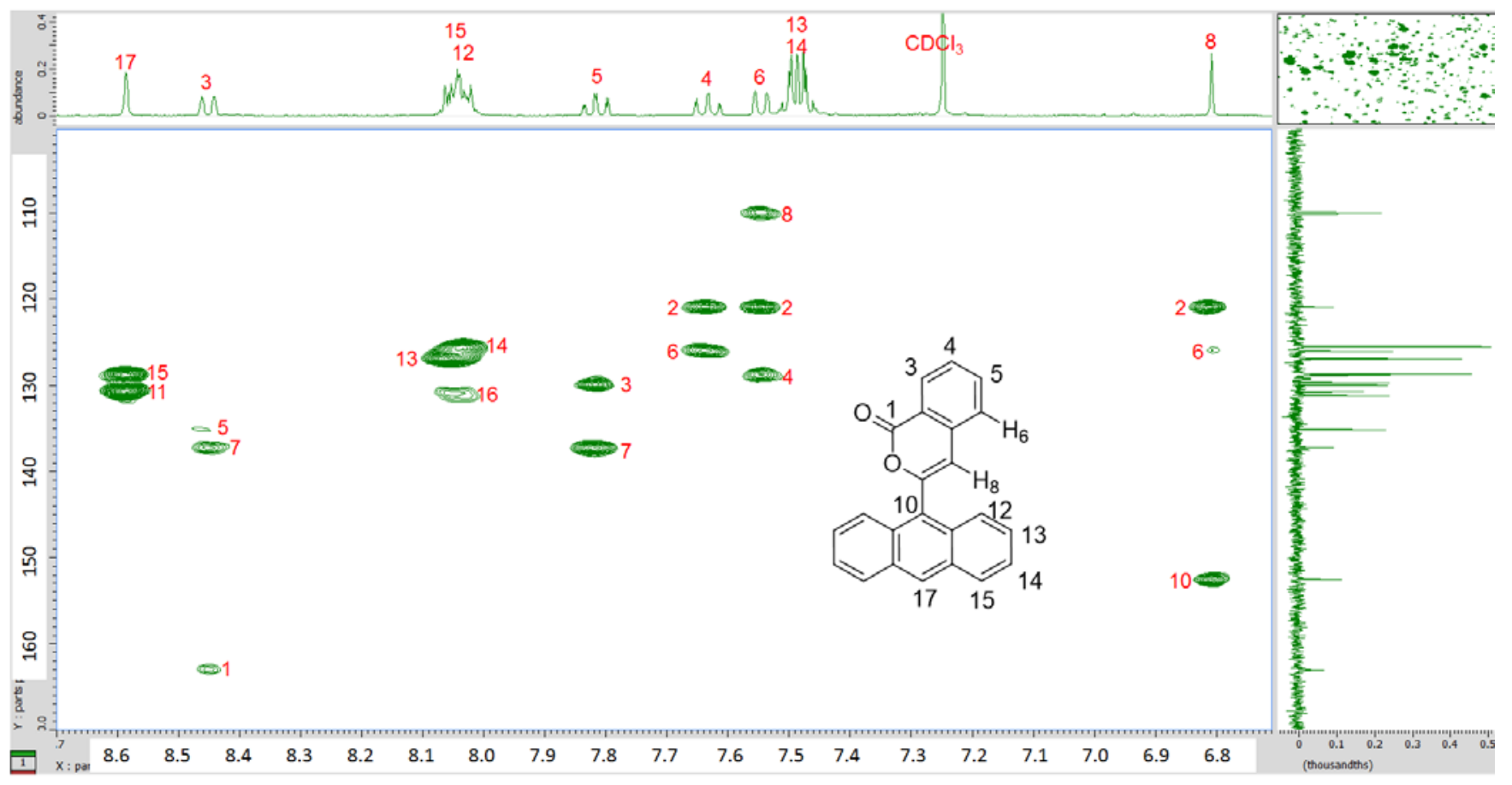

Figure S6. 2D HMBC spectrum of 5e in $\mathrm{CDCl}_{3}$ at $25^{\circ} \mathrm{C}(400 \mathrm{MHz})$ 


\section{Spectroscopic studies}

Table S1. Basic photophysical properties of tolan derivatives. ${ }^{\text {a }}$

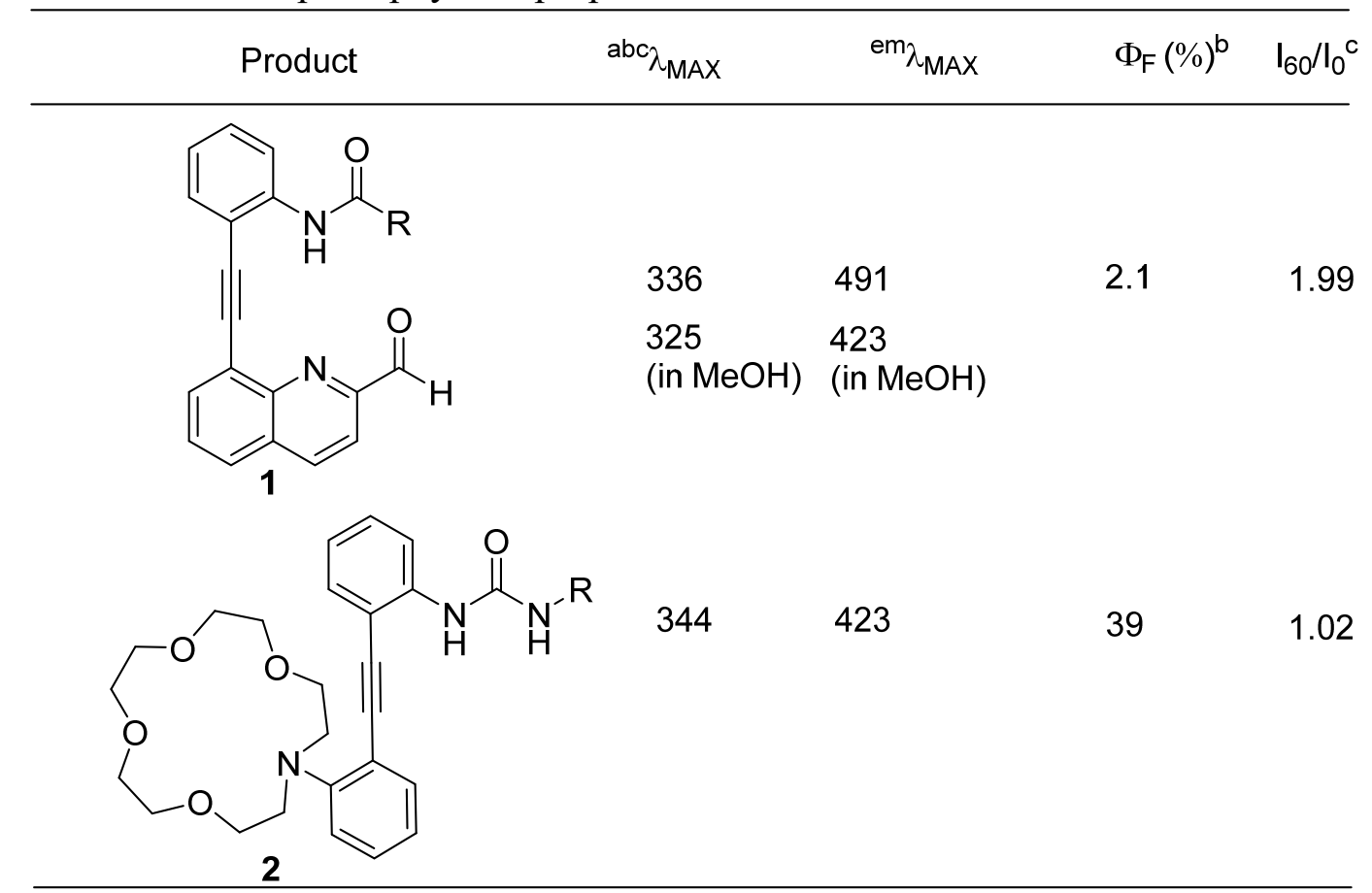

${ }^{\mathrm{a}} \mathrm{All}$ measurements were conducted in $\mathrm{CH}_{3} \mathrm{CN}$ at $25^{\circ} \mathrm{C}$ unless stated.

${ }^{b}$ fluorescence quantum yields were measured in a relative way as compared to the fluorescence quantum yield of 4-methyl-7-aminocoumarin in $\mathrm{CH}_{3} \mathrm{CN}$.

${ }^{c} \mathrm{I}_{60} / \mathrm{I}_{0}$ is the observed fluorescence intensity ratio where $\mathrm{I}_{60}$ is a measured intensity in $60 \%$ glycerol and $\mathrm{I}_{0}$ in $0 \%$ glycerol in $\mathrm{MeOH}$ at their ${ }^{\mathrm{em}} \lambda_{\max }$.

Table S2. Physical and photophysical properties of $\mathbf{5 d}$ in solvents

\begin{tabular}{|c|c|c|c|c|c|}
\hline $\mathbf{5 d}$ & polarity $^{\mathrm{a}}$ & $\begin{array}{c}\text { Viscosity }^{\mathrm{b}} \\
(\mathrm{cPs})\end{array}$ & ${ }^{\mathrm{abc}} \lambda_{\operatorname{MAX}}$ & ${ }^{\mathrm{em}} \lambda_{\mathrm{MAX}}$ & $\Phi_{\mathrm{F}}(\%)$ \\
\hline Acetonitrile & 37.5 & 0.37 & 356 & 429 & 0.305 \\
\hline 1,2-Dichloroethane & $10.5\left(20^{\circ} \mathrm{C}\right)$ & 0.79 & 361 & 429 & 0.357 \\
\hline Dichloromethane & 9.08 & $0.45\left(15^{\circ} \mathrm{C}\right)$ & 361 & 430 & 0.384 \\
\hline Methanol & $32.6\left(25^{\circ} \mathrm{C}\right)$ & 0.55 & 357 & 432 & 0.412 \\
\hline Dimethyl sulfoxide & 48.9 & 2.24 & 362 & 436 & 0.636 \\
\hline
\end{tabular}

${ }^{\text {aT }}$ The dielectric constants of the solvents. b the viscosity of the solvent at $20^{\circ} \mathrm{C}$. 


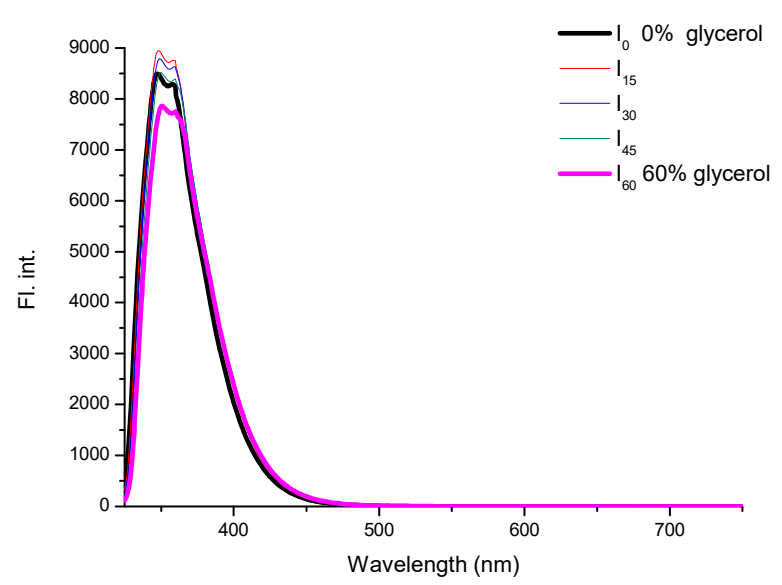

Figure S7. Fluorescence spectra changes of 3a $(5 \mu \mathrm{M})$ in methanol-glycerol mixtures of varied viscosity.

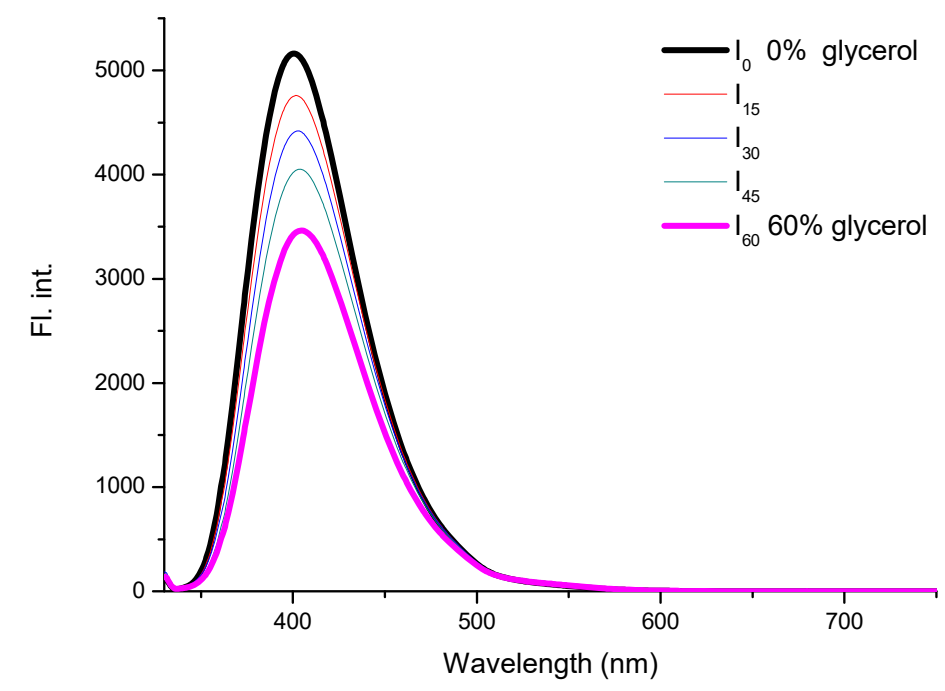

Figure S8. Fluorescence spectra changes of $\mathbf{3 b}(5 \mu \mathrm{M})$ in methanol-glycerol mixtures of varied viscosity. 


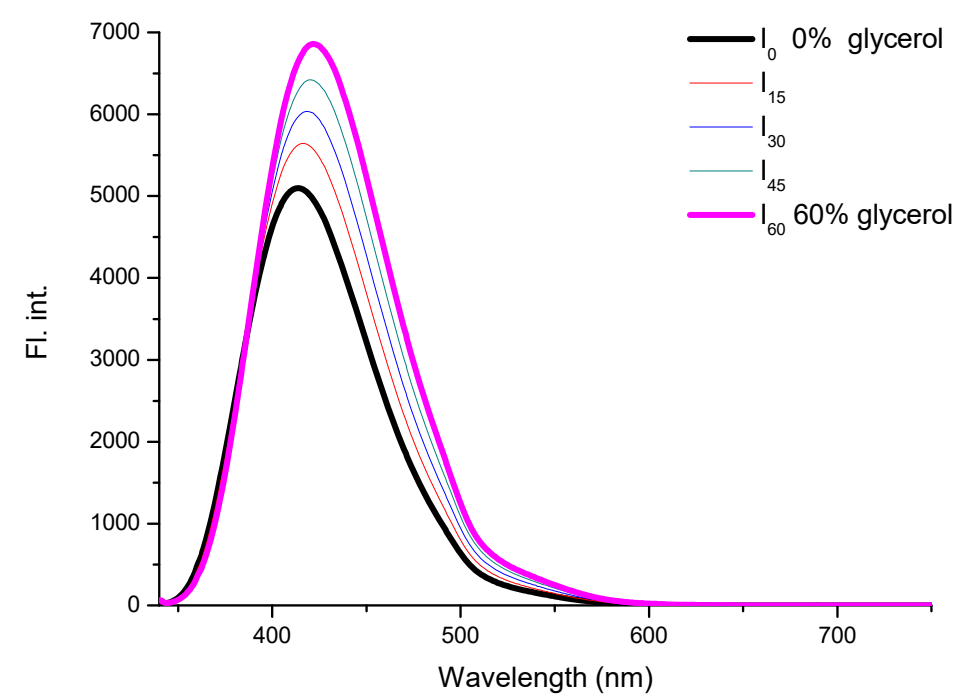

Figure S9. Fluorescence spectra changes of 3c $(5 \mu \mathrm{M})$ in methanol-glycerol mixtures of varied viscosity.

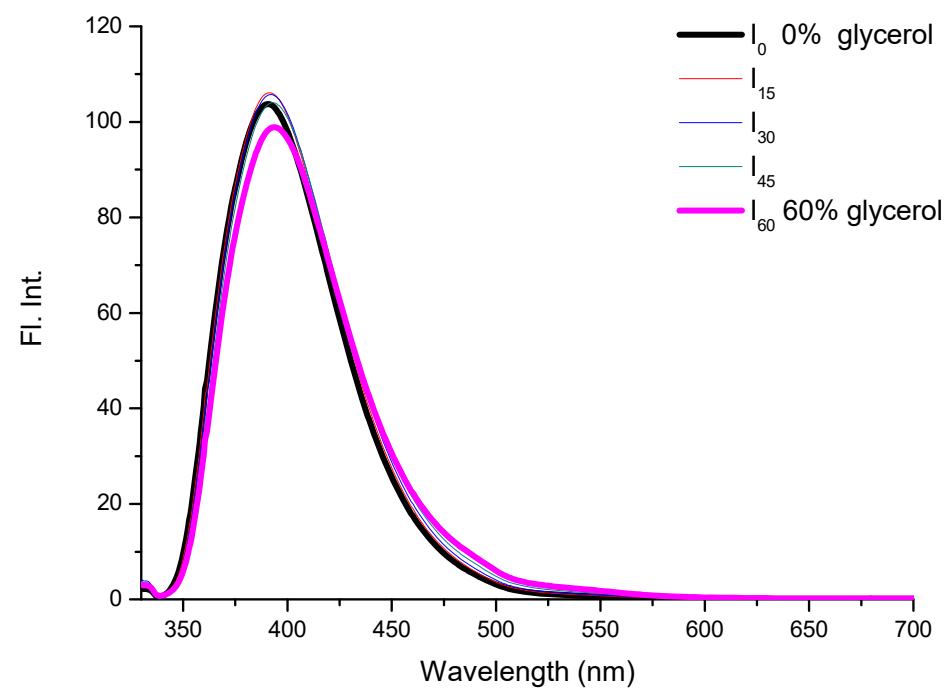

Figure S10. Fluorescence spectra changes of 3d $(5 \mu \mathrm{M})$ in methanol-glycerol mixtures of varied viscosity 


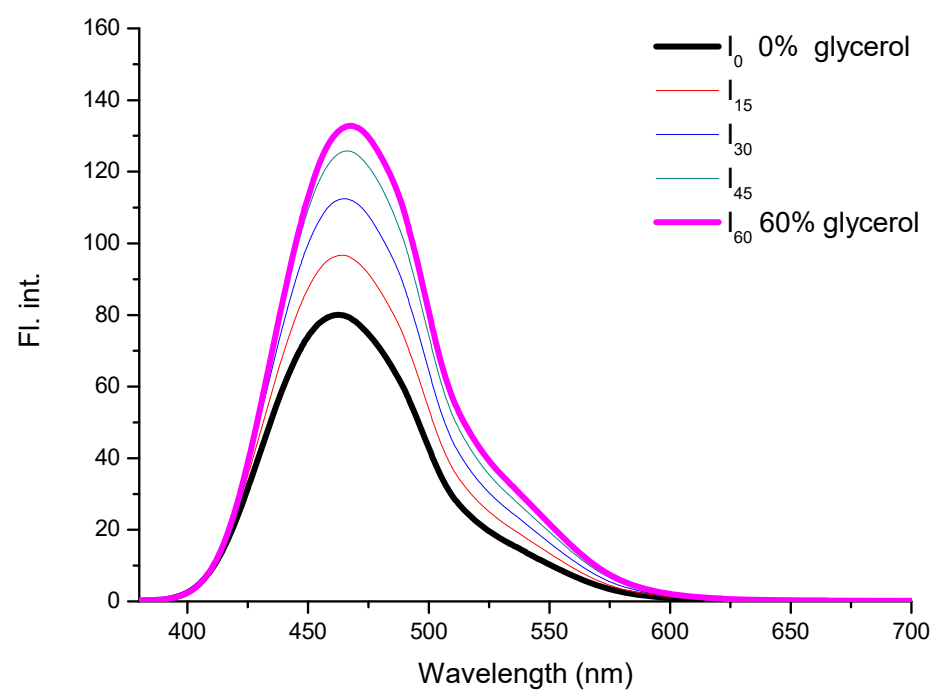

Figure S11. Fluorescence spectra changes of 5c $(5 \mu \mathrm{M})$ in methanol-glycerol mixtures of varied viscosity

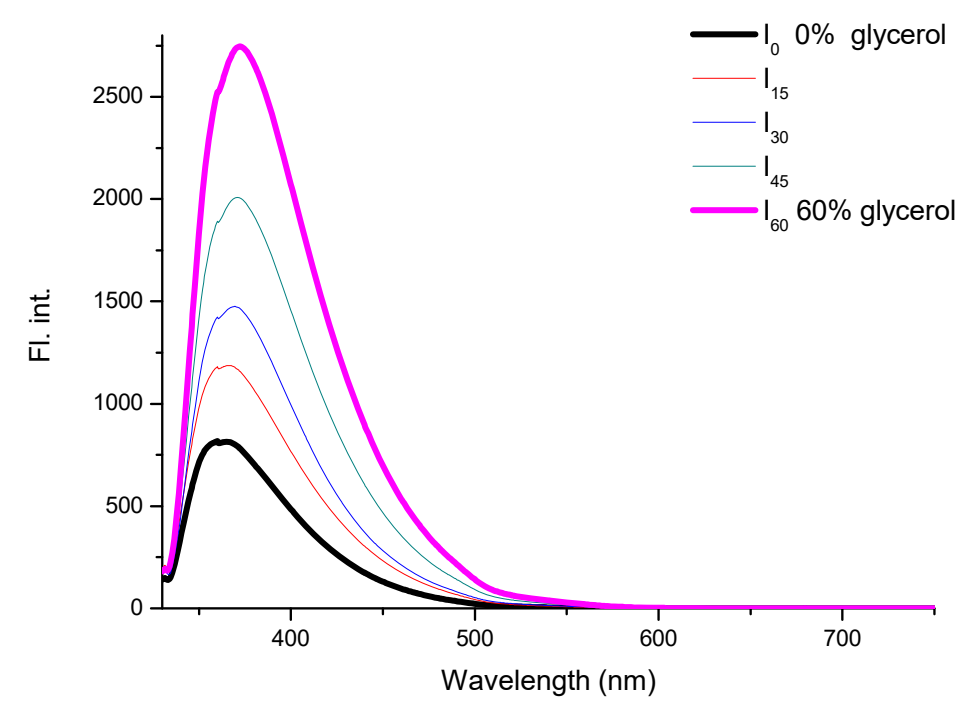

Figure S12. Fluorescence spectra changes of $4 c(5 \mu \mathrm{M})$ in methanol-glycerol mixtures of varied viscosity 


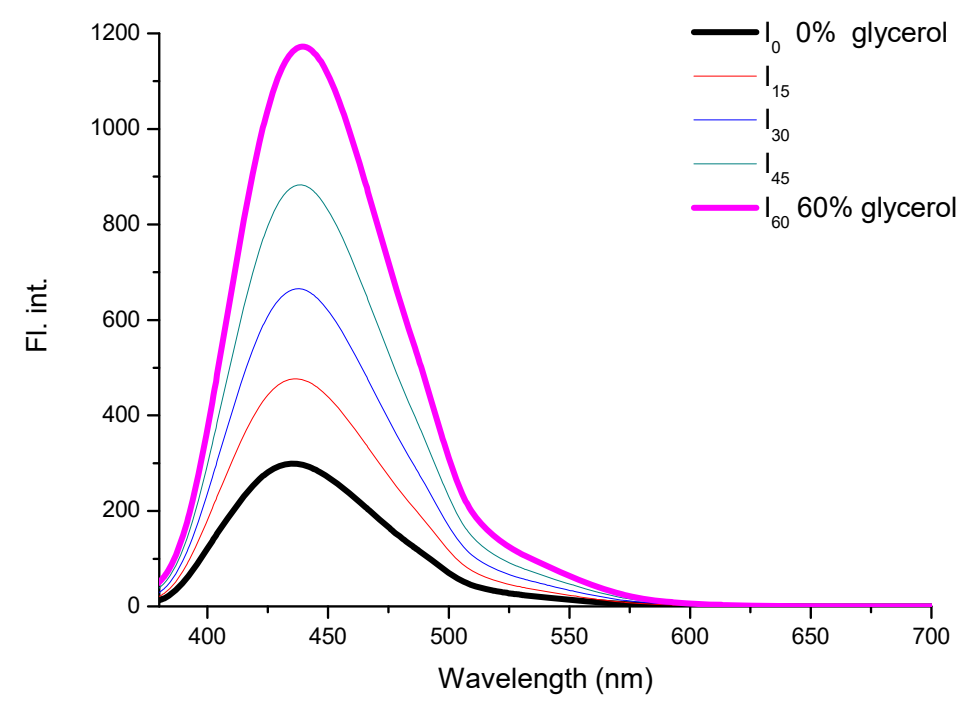

Figure S13. Fluorescence spectra changes of $5 \mathbf{d}(5 \mu \mathrm{M})$ in methanol-glycerol mixtures of varied viscosity.

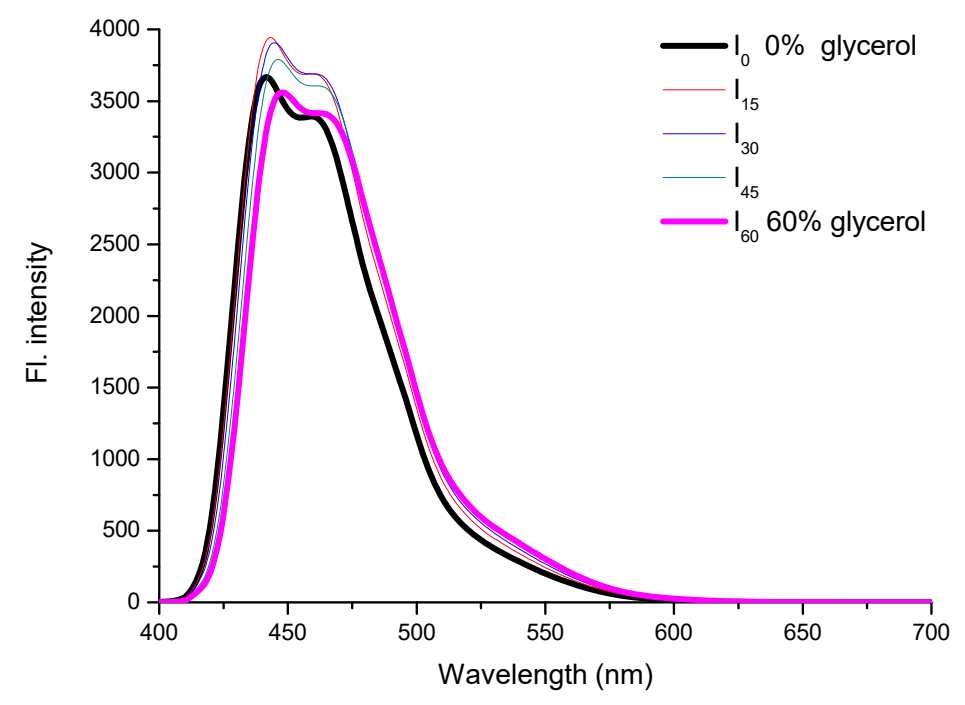

Figure S14. Fluorescence spectra changes of $3 e(5 \mu \mathrm{M})$ in methanol-glycerol mixtures of varied viscosity. 


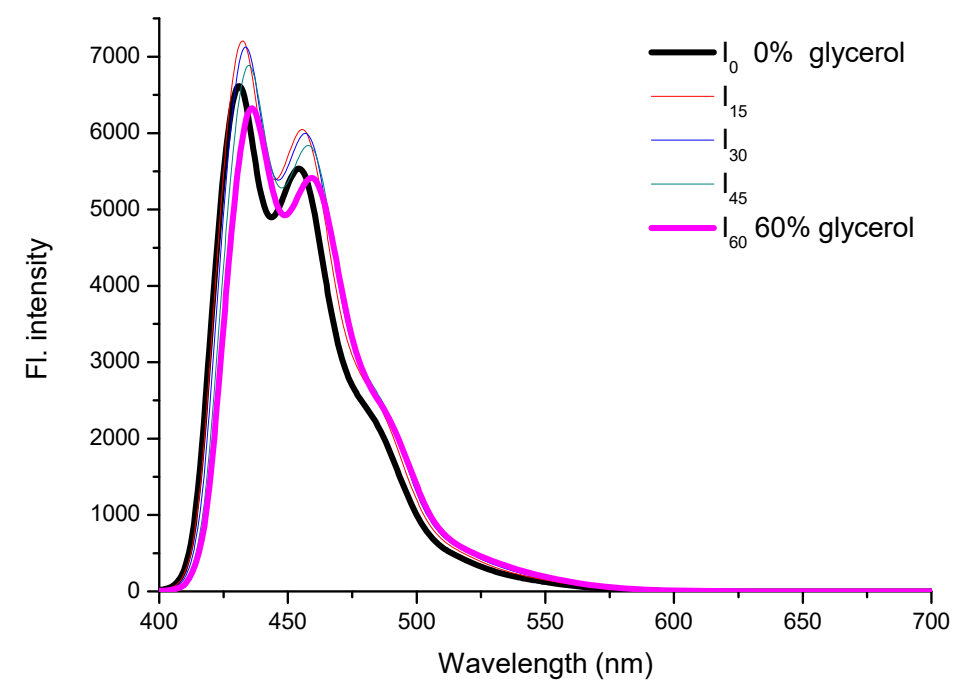

Figure S15. Fluorescence spectra changes of $4 \mathbf{e}(5 \mu \mathrm{M})$ in methanol-glycerol mixtures of varied viscosity.

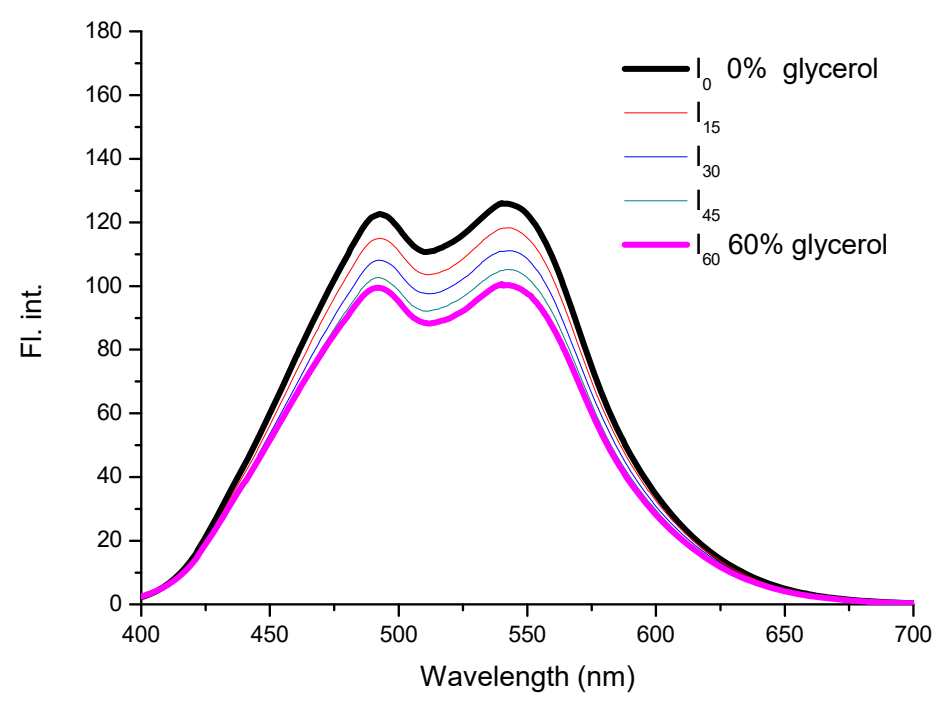

Figure S16. Fluorescence spectra changes of $5 e(5 \mu \mathrm{M})$ in methanol-glycerol mixtures of varied viscosity. 


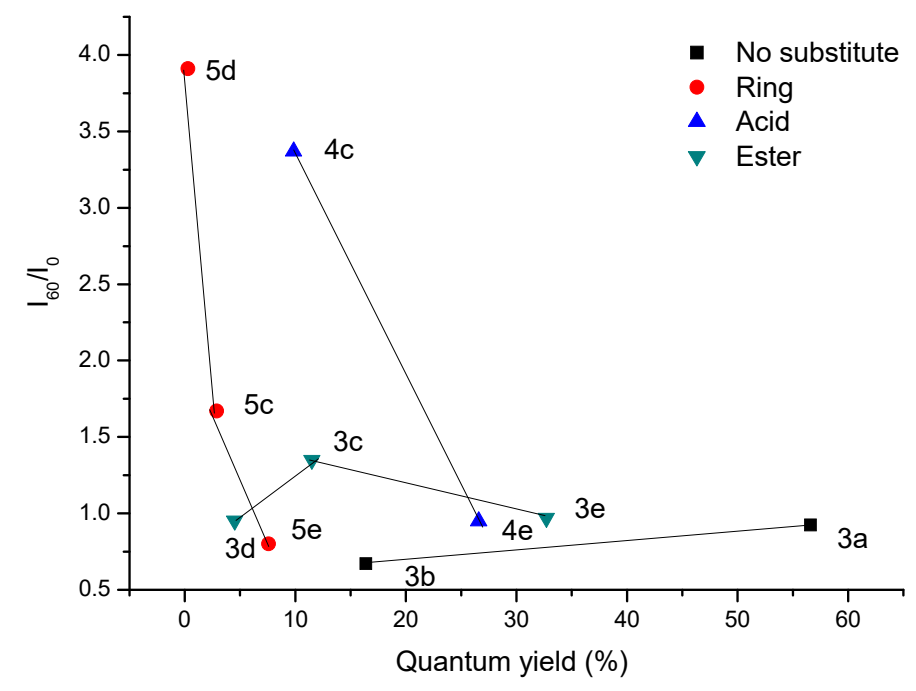

Figure S17. I60/I0 values of tolans against their fluorescence quantum yields in $\mathrm{CH}_{3} \mathrm{CN}$ at $25{ }^{\circ} \mathrm{C}$. All data comes from Table 1 in the current paper.

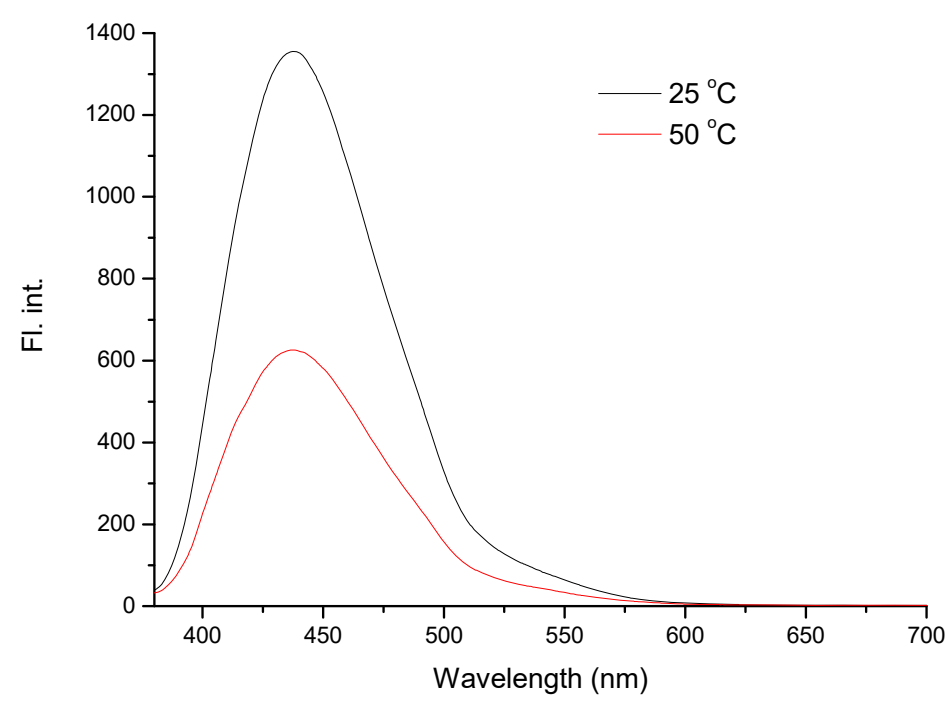

Figure S18. Fluorescence spectra changes of 5d (5 uM in DMSO) upon the excitation at $363 \mathrm{~nm}$ at two different temperatures. 
Fluorescence spectra changes of $5 \mathrm{~d}$ at a various pHs

(a)

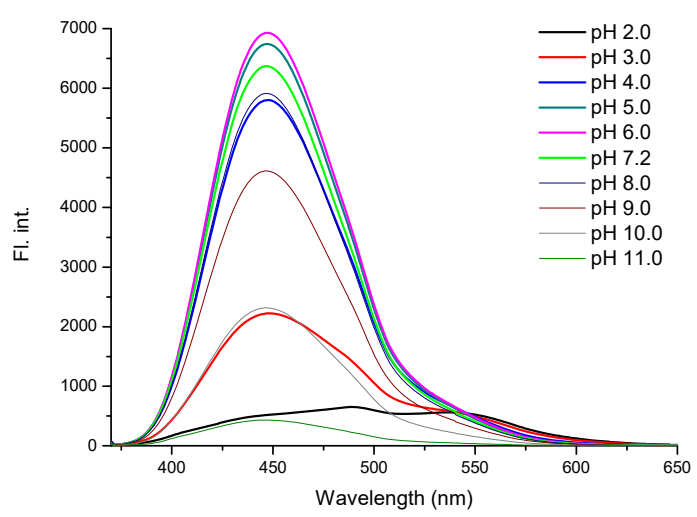

(b)

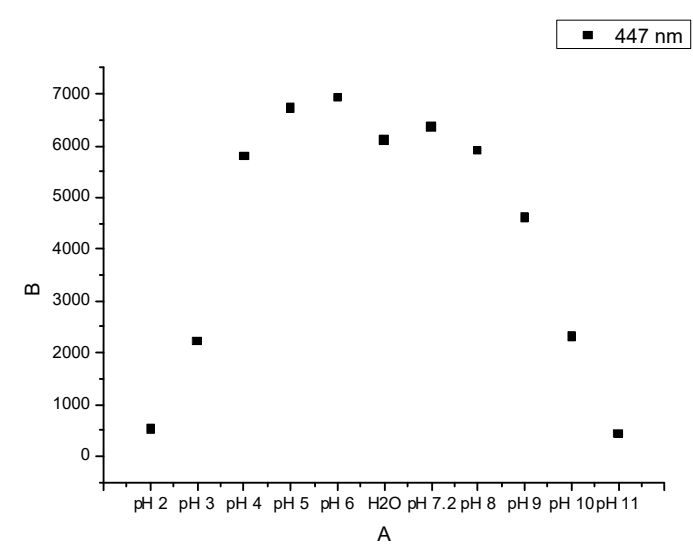

Figure S19. (a) Fluorescence spectra changes and (b) intensity changes of $5 \mathbf{d}(5 \mu \mathrm{M})$ at $447 \mathrm{~nm}$ at a various pHs in $90 \%$ HEPES $(10 \mathrm{mM})$ buffer containing $10 \% \mathrm{MeOH}$

\section{Quantum yields}

The relative quantum vields of tolans were obtained by comparison with the known quantum yields of 4methyl-7-aminocoumarin. In the comparative method, the quantum yields are calculated using the slope of the line determined from the plot of the absorbance against the integrated fluorescence intensities as shown in Table 1. Using this method, the quantum yields were calculated using the equation: $Q=$ $Q_{r}\left(m / m_{r}\right)\left(n / n_{r}\right)$, where $m$ is the slope of the line obtained from the plot of the integrated fluorescence intensity vs. absorbance; $n$ is the refractive index of the solvent and the subscript $r$ refers to Coumarin-120 of known quantum yield. The value of $\left(n / n_{r}\right)$ is unity if the measurements of the unknown compounds are conducted in the same solvent used for the reference compounds. 


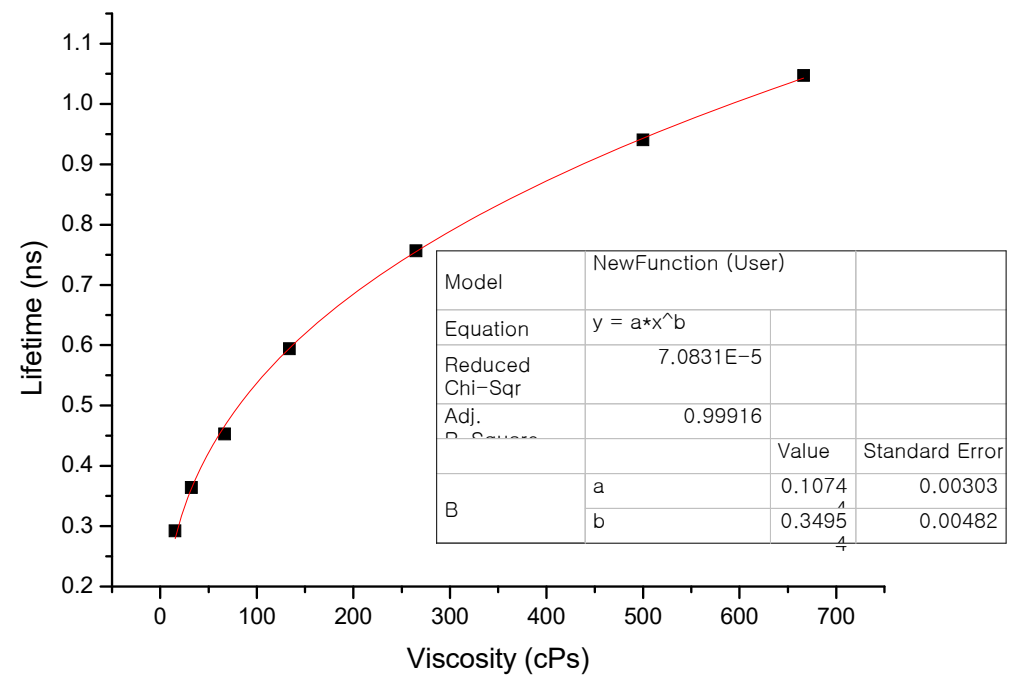

Figure S20. Plot of fluorescence lifetime $(\tau)$ of $\mathbf{5 d}$ vs viscosity $(\eta)$ that fits to the equation of $\tau=z k 0 \eta^{\alpha}$ where $k_{0}$ is the radiative rate constant, and $z$ and $\alpha$ are constants. 


\section{Properties of $5 \mathrm{~d}$ as a viscosity sensor}

\section{Determination of Viscosity and Fluorescence Lifetime}

Viscosity was measured with a DV-1viscometer at $25{ }^{\circ} \mathrm{C}$. Each solution of $\mathbf{5 d}$ with a specific viscosity were prepared by adding $1 \mathrm{~mL}$ of $\mathbf{5 d}(0.05 \mathrm{mM}$ in $\mathrm{MeOH})$ to $9 \mathrm{~mL}$ of solvent mixture (methanol-glycerol systems) to obtain the final concentration of $5 \mathbf{d}(5 \mu \mathrm{M})$. These solutions were shaken for $0.5 \mathrm{~min}$. After standing for 2 hours at $25{ }^{\circ} \mathrm{C}$ to eliminate air bubbles, the solutions were measured in a UV spectrophotometer and a fluorescence spectrophotometer. A Fluo Time 200 lifetime fluorometer was used to obtain the fluorescence lifetimes of compounds, with the excitation wavelength at $375 \mathrm{~nm}$ and detection at $441 \mathrm{~nm}$.

\section{Cell Incubation}

HeLa cells were cultured in DEME (Invitrogen) supplemented with 10\% FCS (Invitrogen). One day before imaging, cells were seeded into 24-well flat-bottomed plates. The next day, the cells were incubated with $5.0 \mu \mathrm{M}$ of $\mathbf{5 d}$ for $0.5 \mathrm{~h}$ at $37^{\circ} \mathrm{C}$ under $5 \% \mathrm{CO}_{2}$ and washed with phosphate-buffered saline (PBS) three times. Cells were fixed for 10 minutes at room temperature with $4 \%$ paraformaldehyde in PBS followed by 2-3 washes with PBS to remove excess formaldehyde.

\section{Experimental details for fluorescence lifetime measurement}

Probe molecule immersed cells as well as control cells were imaged using a confocal microscope (TCS SP8, Leica). Fluorescence lifetime imaging (FLIM) study was performed using an inverted-type scanning confocal microscope (MicroTime-200, Picoquant, Germany) with a 40× (air) objective (UPLSAPO, Olympus). The lifetime measurements were performed at the Korea Basic Science Institute (KBSI), Daegu Center, Korea. Single-mode pulsed diode lasers (375 $\mathrm{nm}$ with a pulse width of $\sim 30 \mathrm{ps}$ ) were used as excitation sources. A dichroic mirror (Z375RDC, AHF), a longpass filter (HQ405lp, AHF), a $75 \mu \mathrm{m}$ pinhole, a band-pass filter, and an avalanche photodiode detector (PDM series, MPD) were used to collect emissions from the cells. Time-correlated singlephoton counting (TCSPC) technique was used to count fluorescence photons. TRPL images consisted of $200 \times 200$ pixels were recorded using the time-tagged time-resolved (TTTR) data acquisition method. Exponential fittings for the obtained fluorescence decays with a temporal resolution of $8 \mathrm{ps}$ were performed using Symphotime-64 software

(Ver. 2.2) by the bi-exponential decay model; $/(t)=\sum A_{j} e^{-t / \tau_{i}}$, where $I(t)$ is the time-dependent PL intensity, $A$ is the amplitude, $\tau$ is the PL lifetime, and $i$ is 2. 
NMR Spectra of tolan derivatives

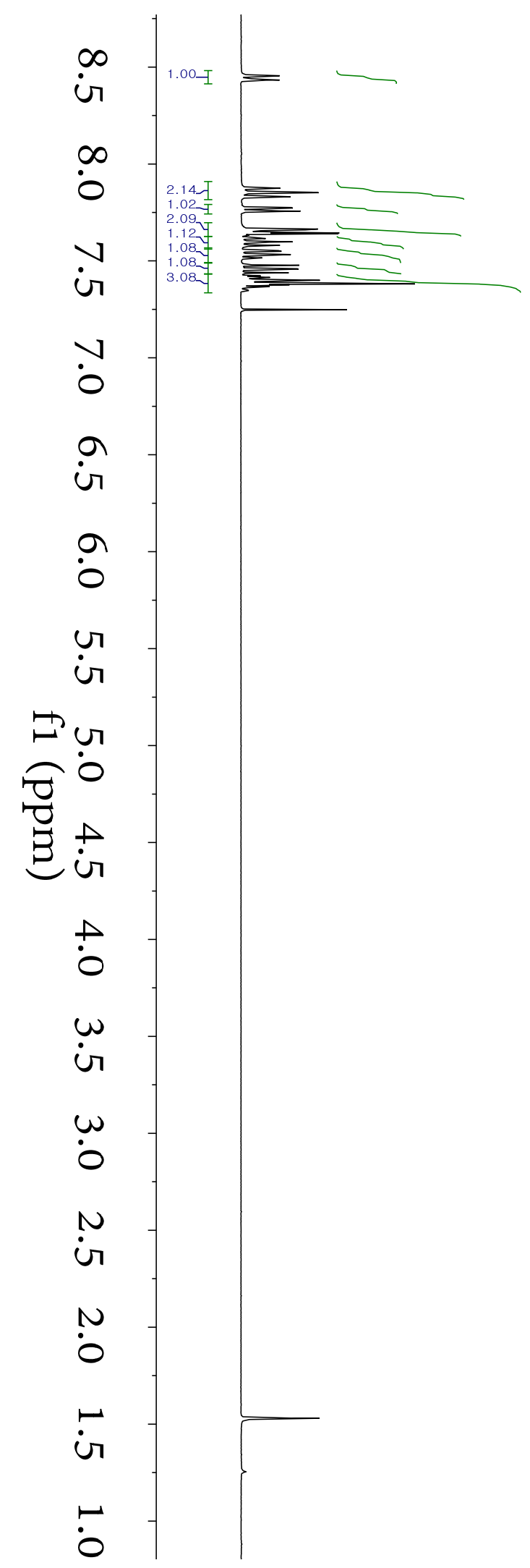

Figure S21. ${ }^{1} \mathrm{H}$ NMR spectrum of $\mathbf{3 a}$ recorded in $\mathrm{CDCl}_{3}$ at $25^{\circ} \mathrm{C}(400 \mathrm{MHz})$ 


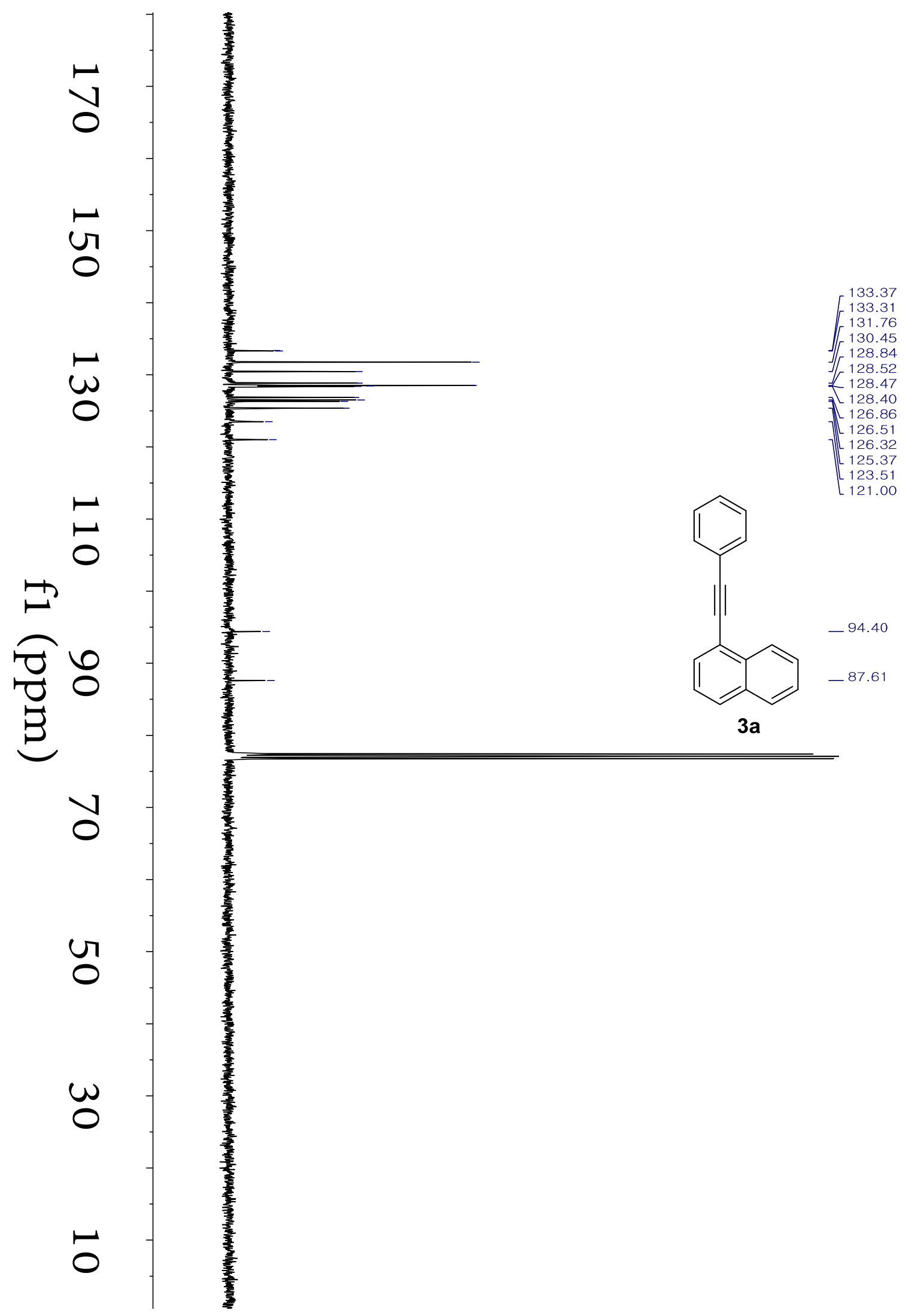

Figure S22. ${ }^{13} \mathrm{C}$ NMR spectrum of $\mathbf{3 a}$ recorded in $\mathrm{CDCl}_{3}$ at $25^{\circ} \mathrm{C}(400 \mathrm{MHz})$ 

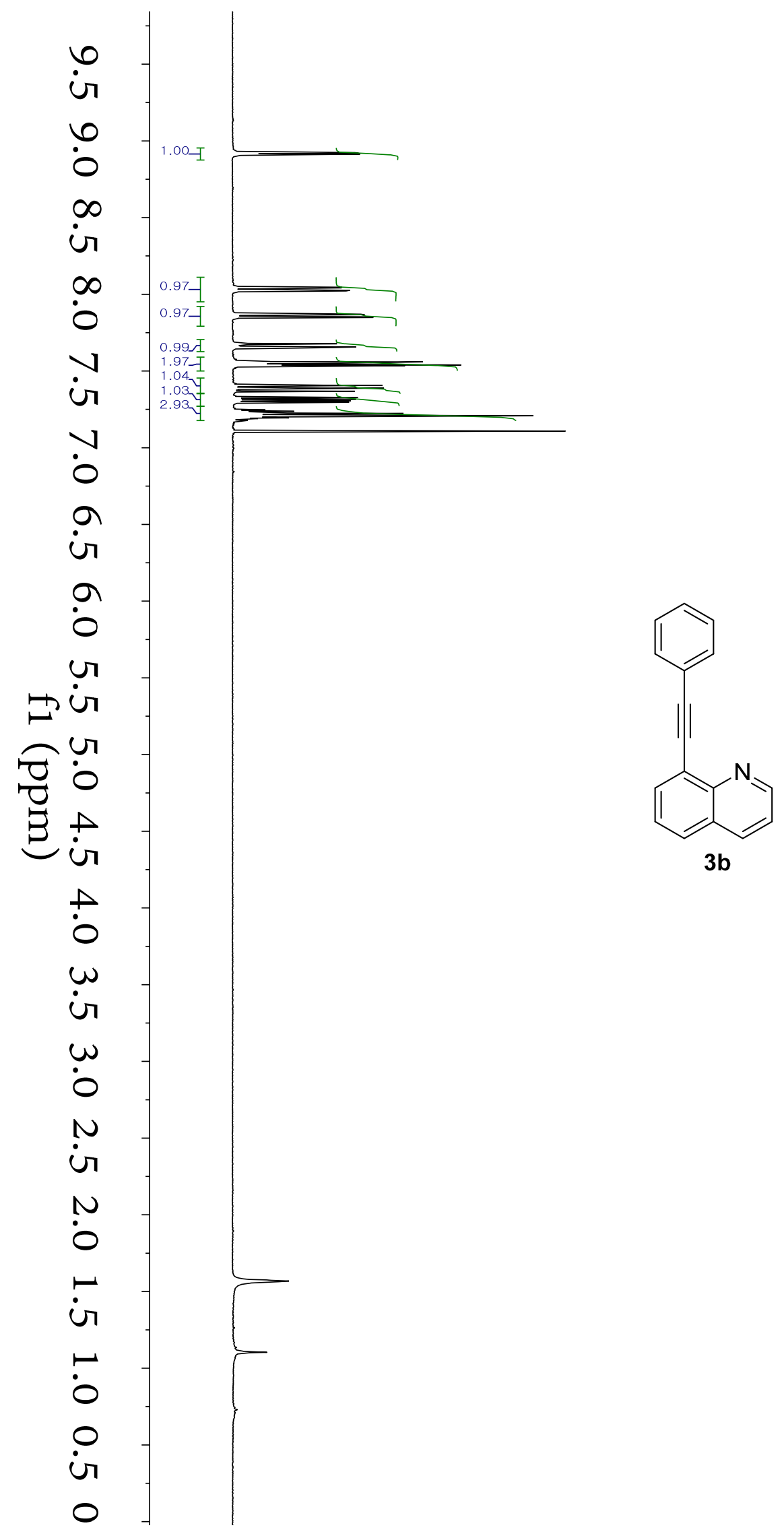

Figure S23. ${ }^{1} \mathrm{H}$ NMR spectrum of $\mathbf{3 b}$ recorded in $\mathrm{CDCl}_{3}$ at $25^{\circ} \mathrm{C}(400 \mathrm{MHz})$ 


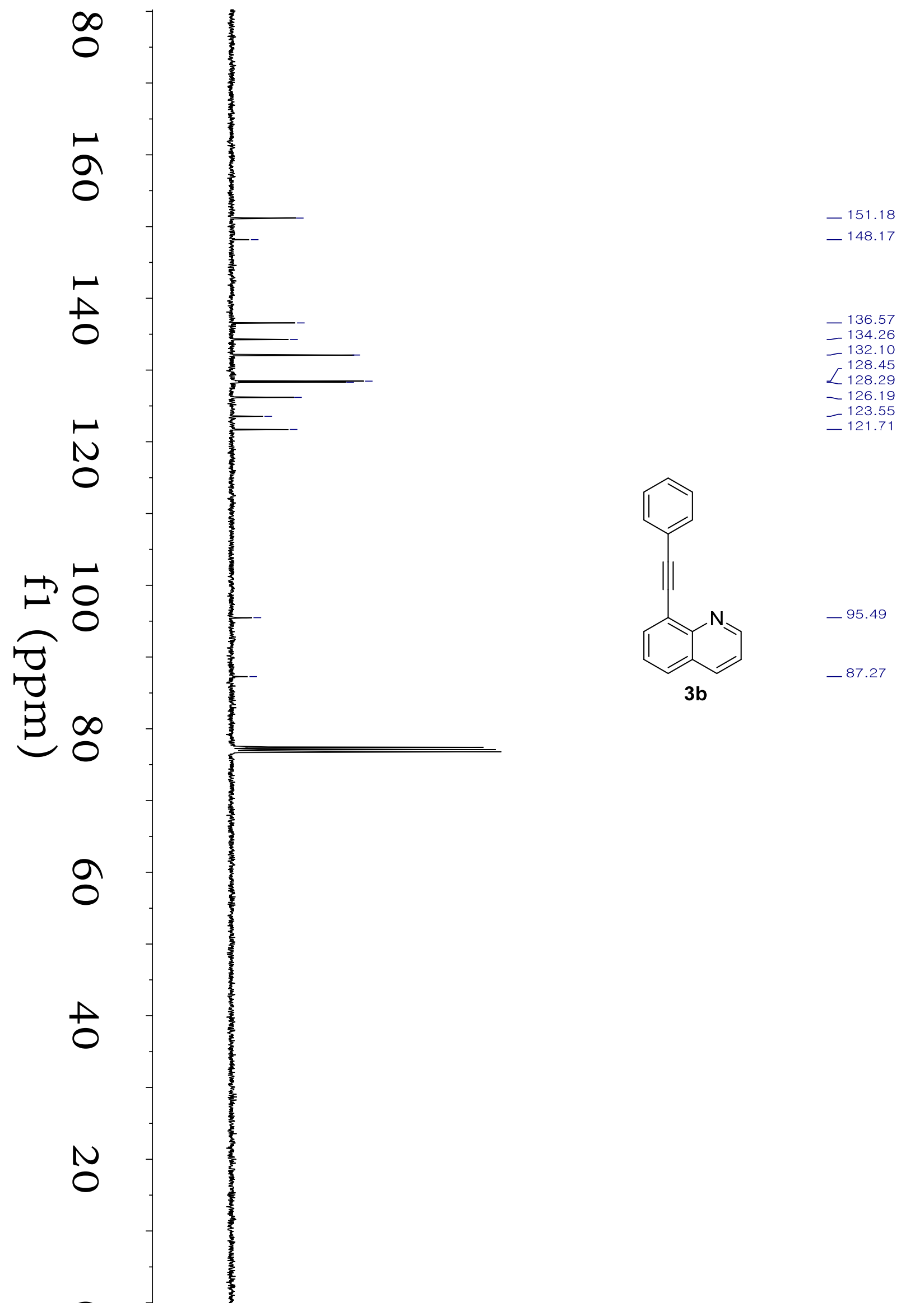

Figure S24. ${ }^{13} \mathrm{C}$ NMR spectrum of $\mathbf{3 b}$ recorded in $\mathrm{CDCl}_{3}$ at $25^{\circ} \mathrm{C}(400 \mathrm{MHz})$ 


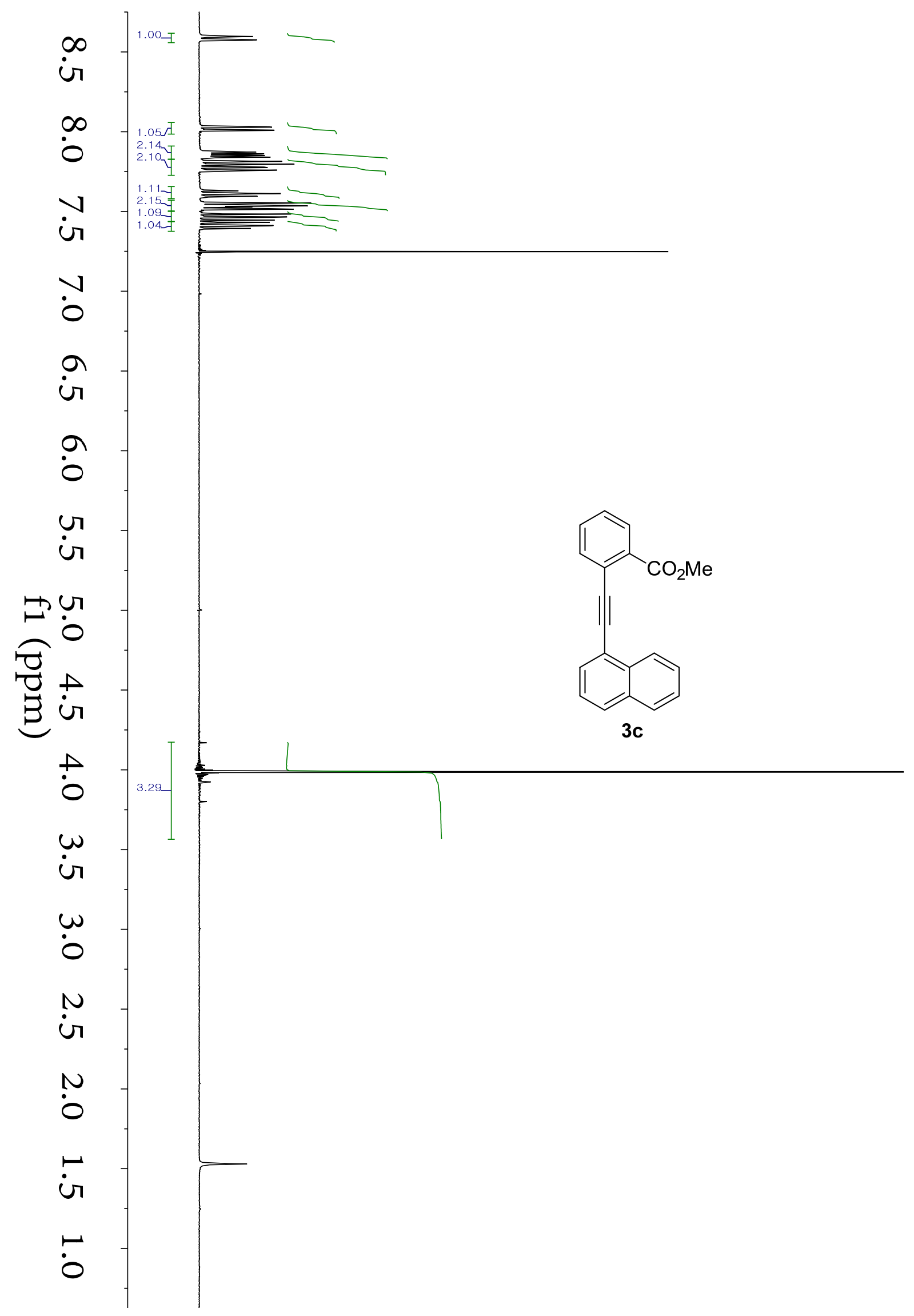

Figure S25. ${ }^{1} \mathrm{H}$ NMR spectrum of $3 \mathbf{c}$ recorded in $\mathrm{CDCl}_{3}$ at $25^{\circ} \mathrm{C}(400 \mathrm{MHz})$ 


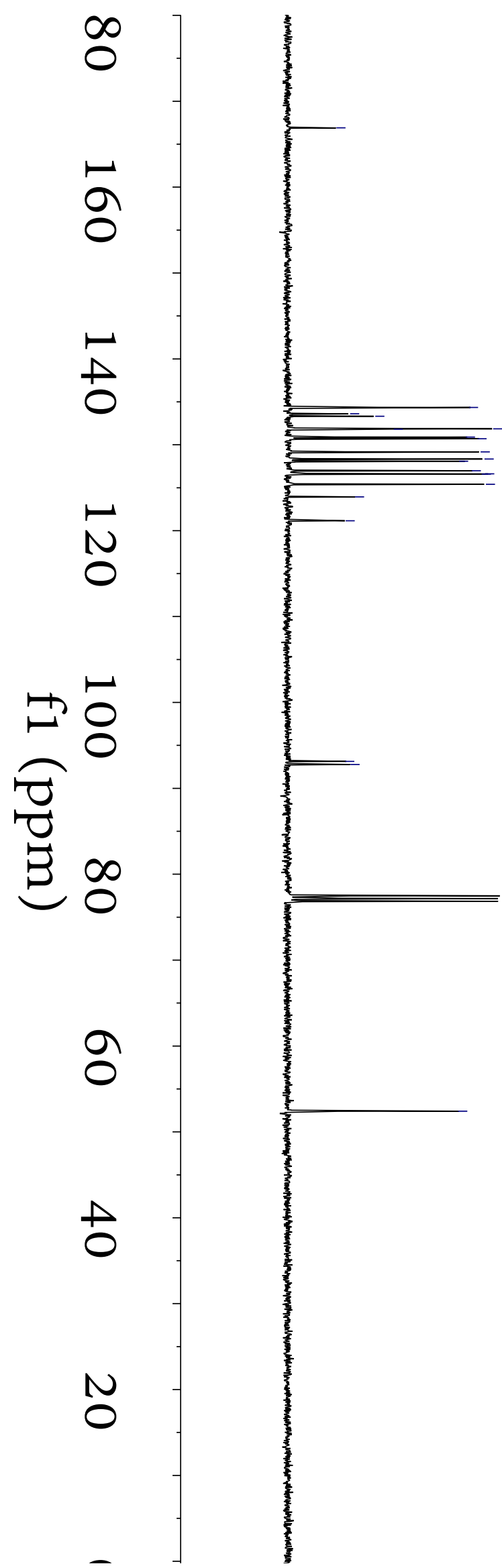

$-166.90$
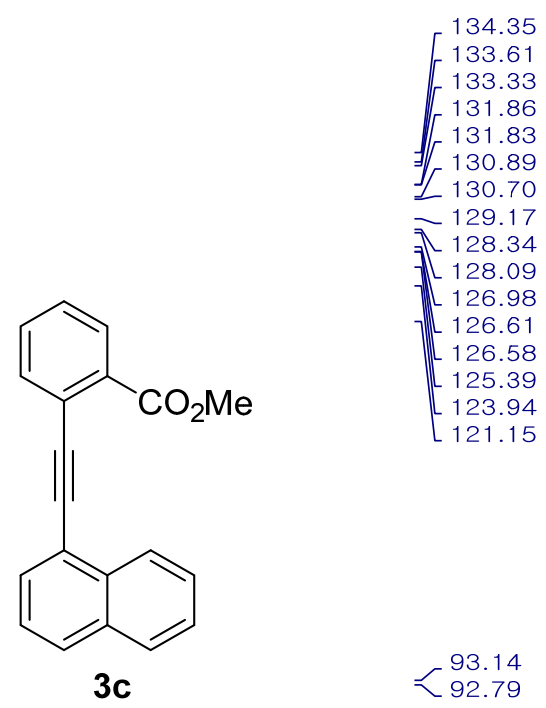

Figure S26. ${ }^{13} \mathrm{C}$ NMR spectrum of $3 \mathbf{c}$ recorded in $\mathrm{CDCl}_{3}$ at $25^{\circ} \mathrm{C}(400 \mathrm{MHz})$ 


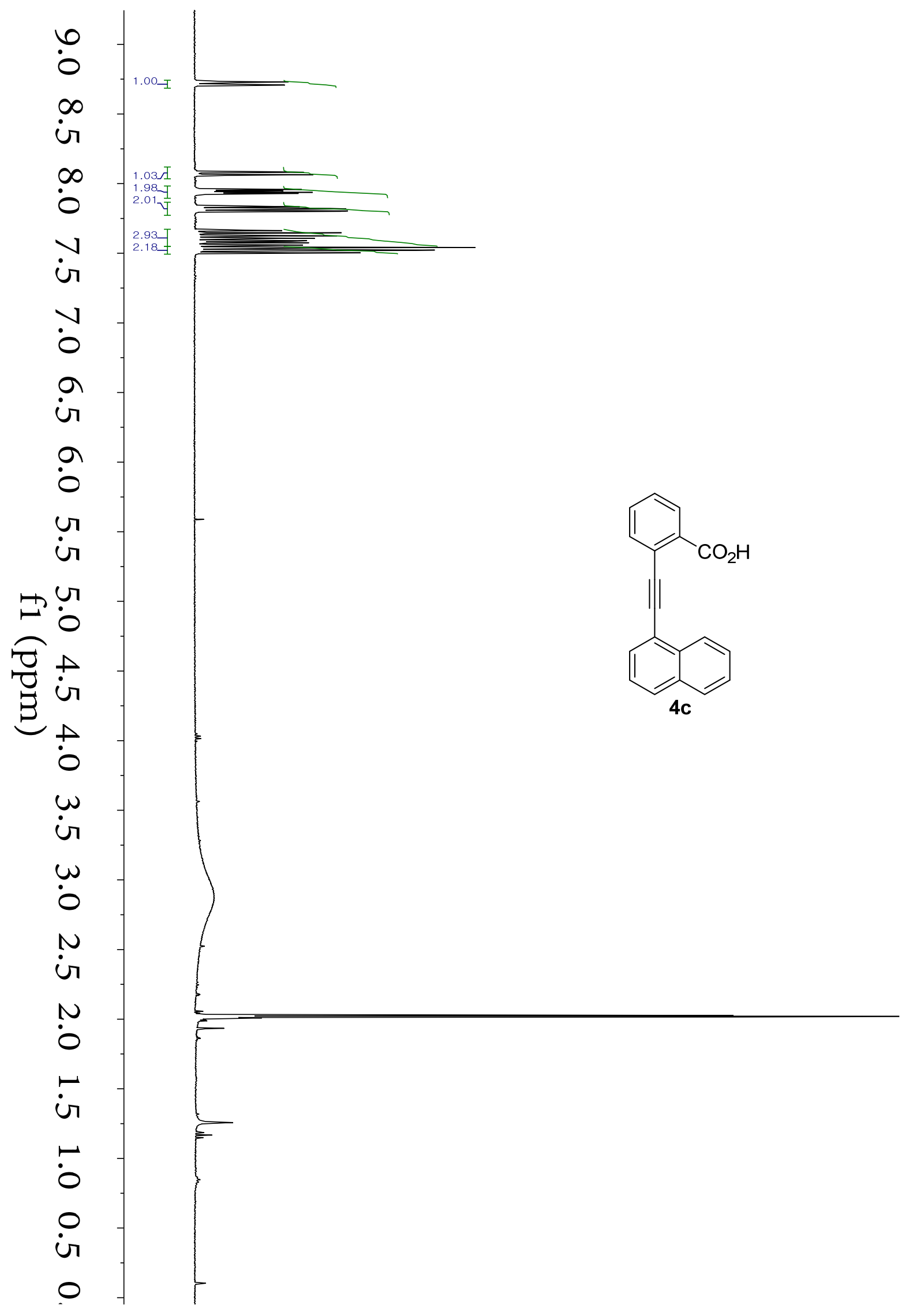

Figure S27. ${ }^{1} \mathrm{H}$ NMR spectrum of $4 \mathbf{c}$ recorded in acetone- $d_{6}$ at $25^{\circ} \mathrm{C}(400 \mathrm{MHz})$ 


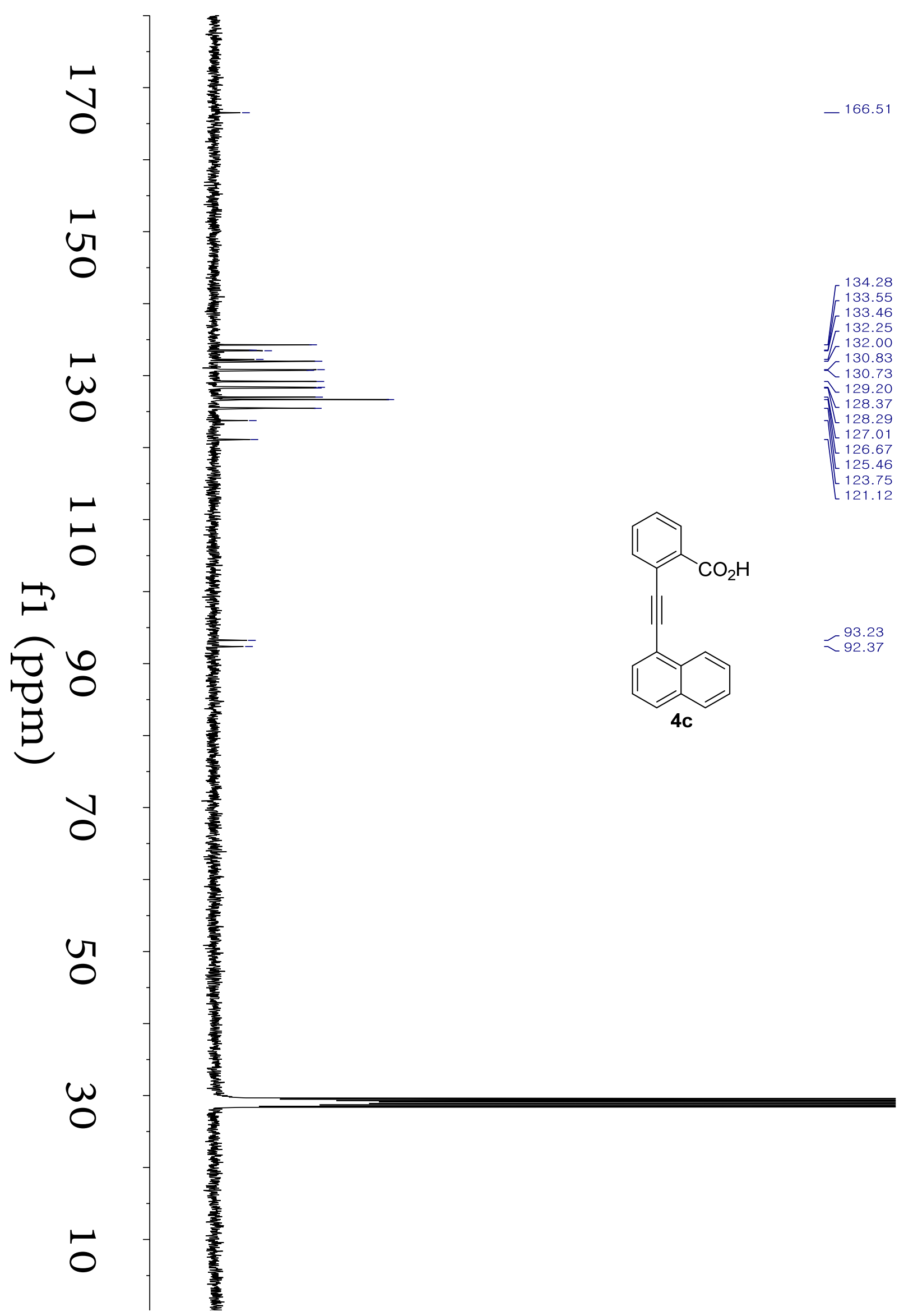

Figure S28. ${ }^{13} \mathrm{C}$ NMR spectrum of $4 \mathbf{c}$ recorded in acetone- $d_{6}$ at $25^{\circ} \mathrm{C}(400 \mathrm{MHz})$ 


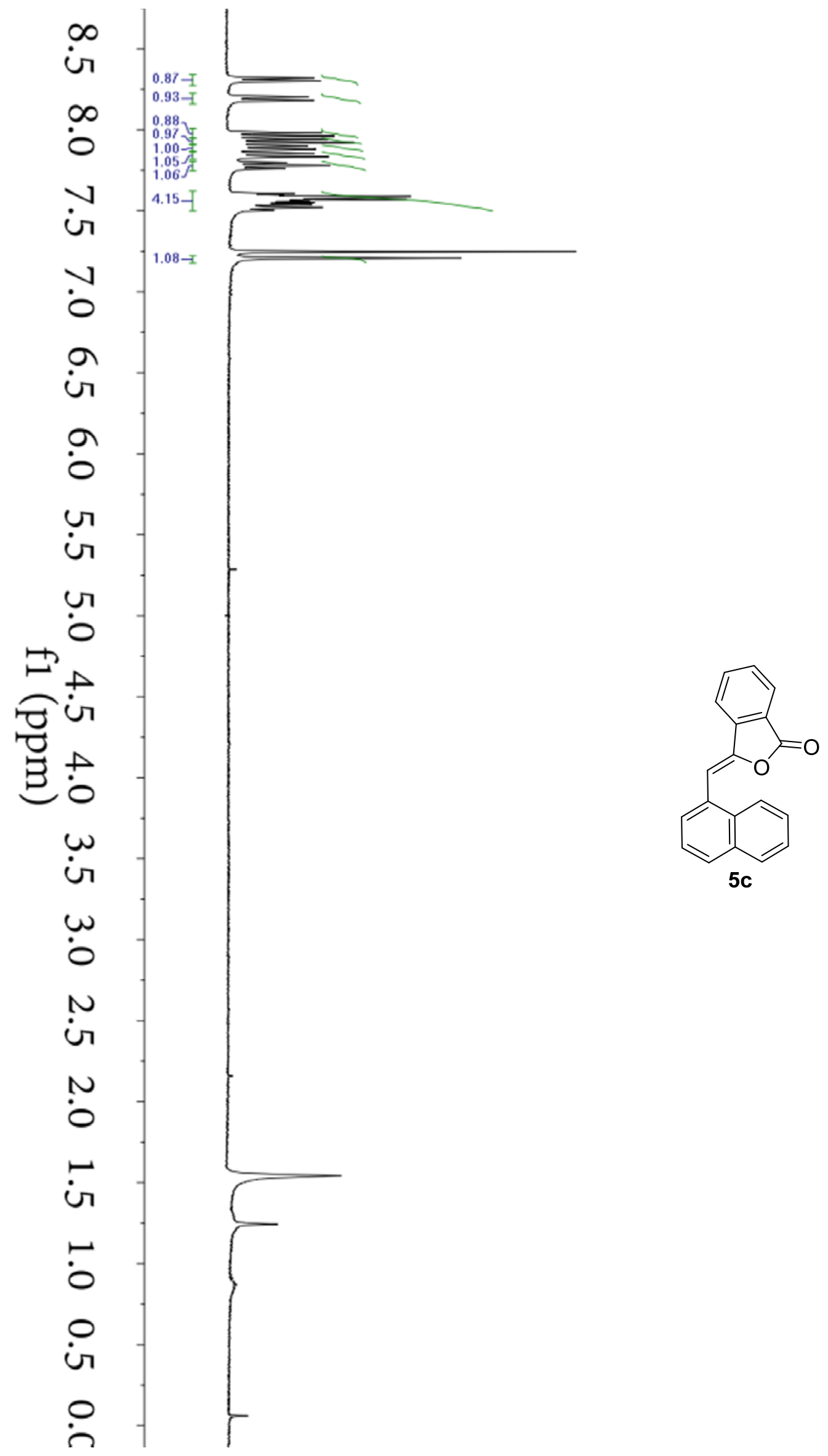

Figure S29. ${ }^{1} \mathrm{H}$ NMR spectrum of $5 \mathbf{c}$ recorded in $\mathrm{CDCl}_{3}$ at $25^{\circ} \mathrm{C}(400 \mathrm{MHz})$ 


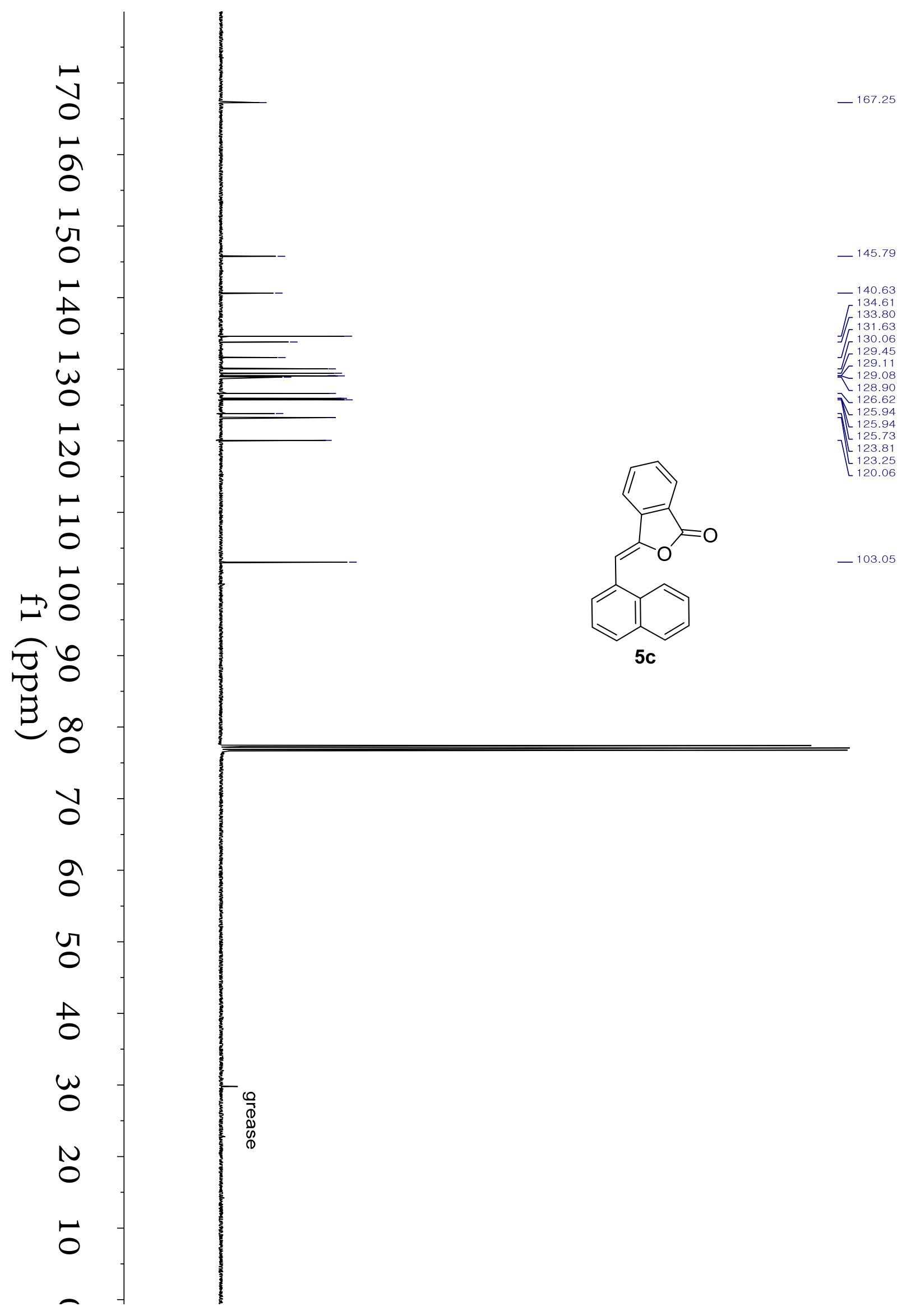

Figure S30. ${ }^{13} \mathrm{C}$ NMR spectrum of $\mathbf{5 c}$ recorded in $\mathrm{CDCl}_{3}$ at $25^{\circ} \mathrm{C}(400 \mathrm{MHz})$ 


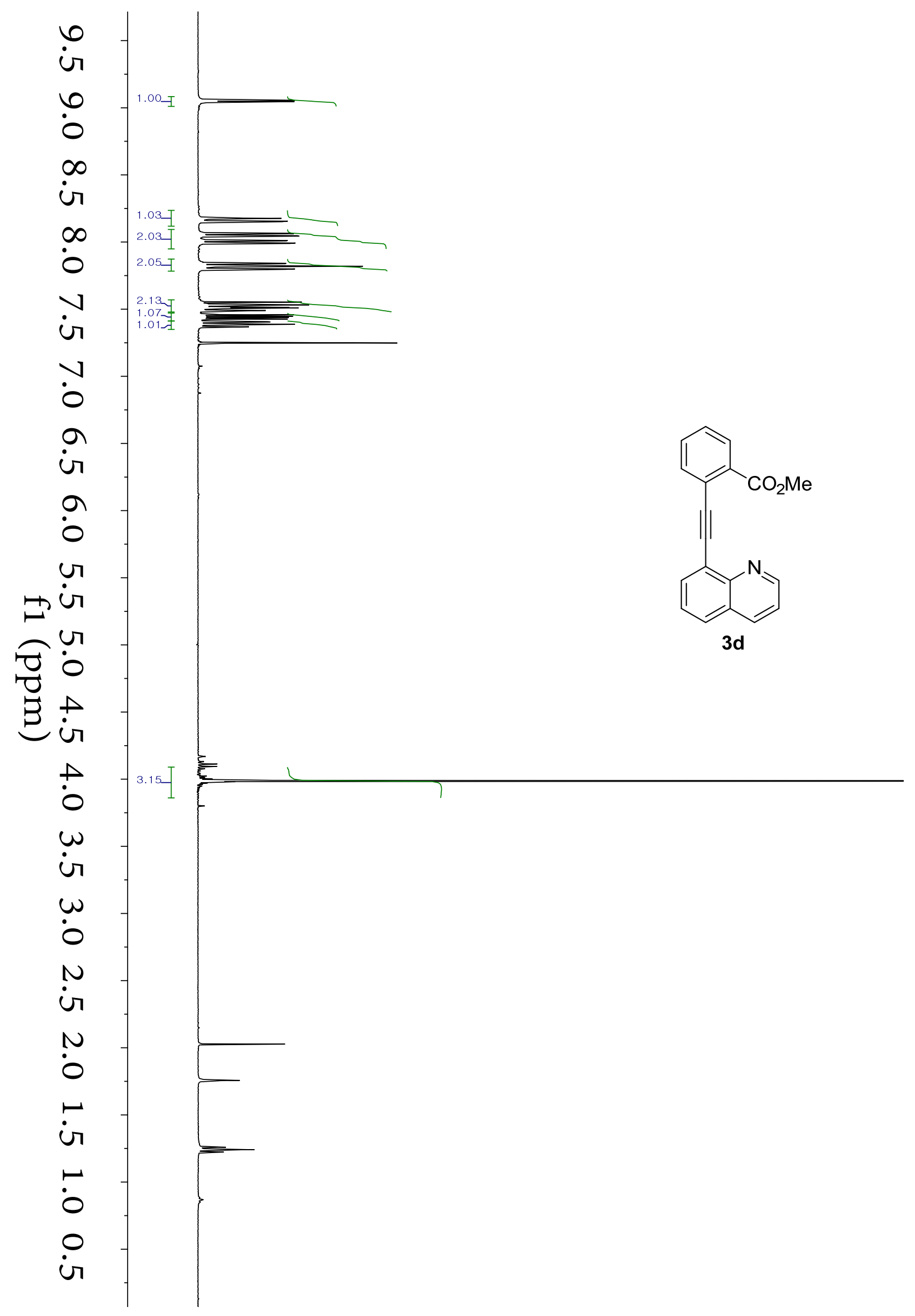

Figure S31. ${ }^{1} \mathrm{H}$ NMR spectrum of $\mathbf{3 d}$ recorded in $\mathrm{CDCl}_{3}$ at $25^{\circ} \mathrm{C}(400 \mathrm{MHz})$ S28 


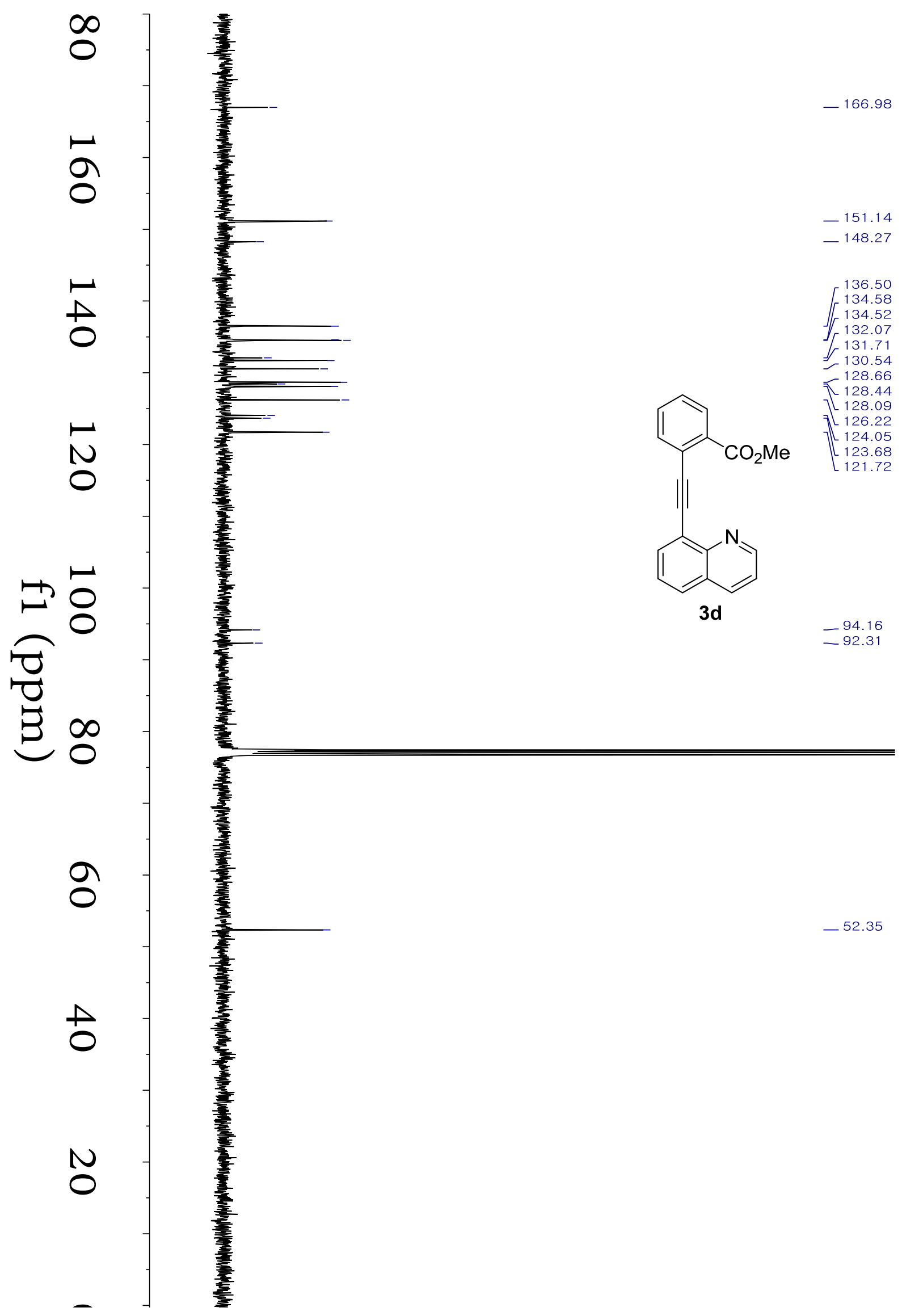

Figure S32. ${ }^{13} \mathrm{C}$ NMR spectrum of $\mathbf{3 d}$ recorded in $\mathrm{CDCl}_{3}$ at $25^{\circ} \mathrm{C}(400 \mathrm{MHz})$ 


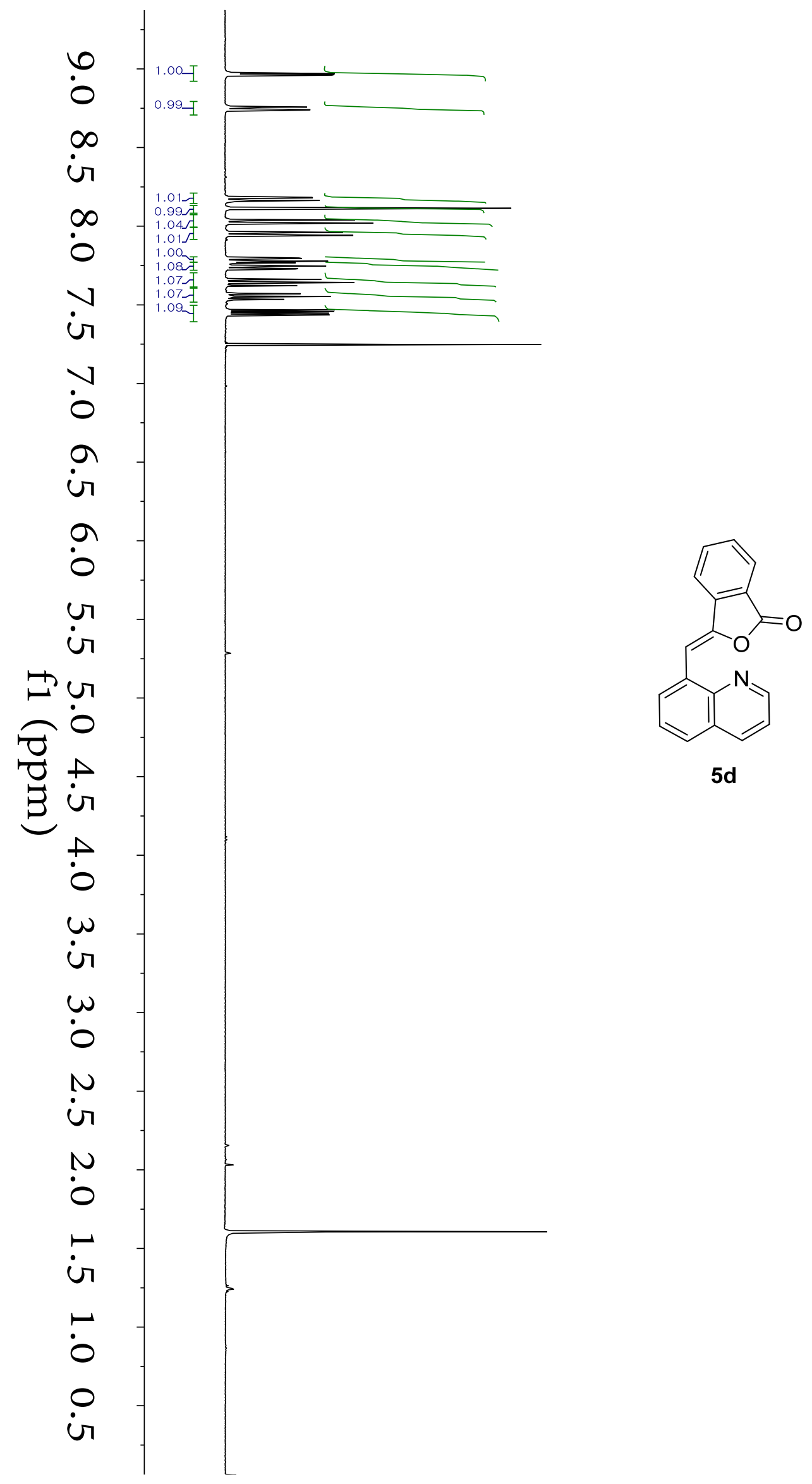

Figure S33. ${ }^{1} \mathrm{H}$ NMR spectrum of $5 \mathbf{d}$ recorded in $\mathrm{CDCl}_{3}$ at $25^{\circ} \mathrm{C}(400 \mathrm{MHz})$ $\mathrm{S} 30$ 


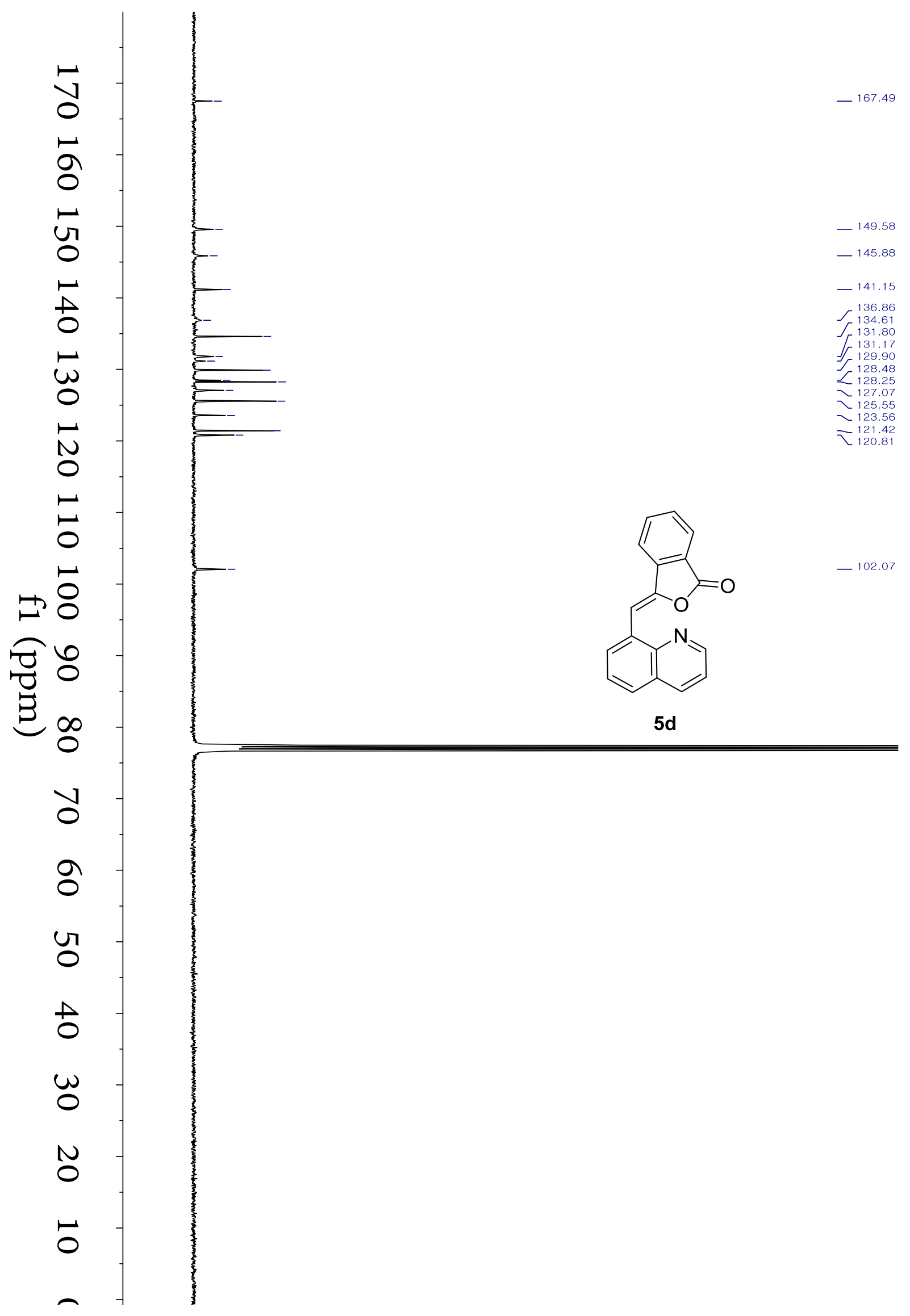

Figure S34. ${ }^{13} \mathrm{C}$ NMR spectrum of $\mathbf{5 d}$ recorded in $\mathrm{CDCl}_{3}$ at $25^{\circ} \mathrm{C}(400 \mathrm{MHz})$ 


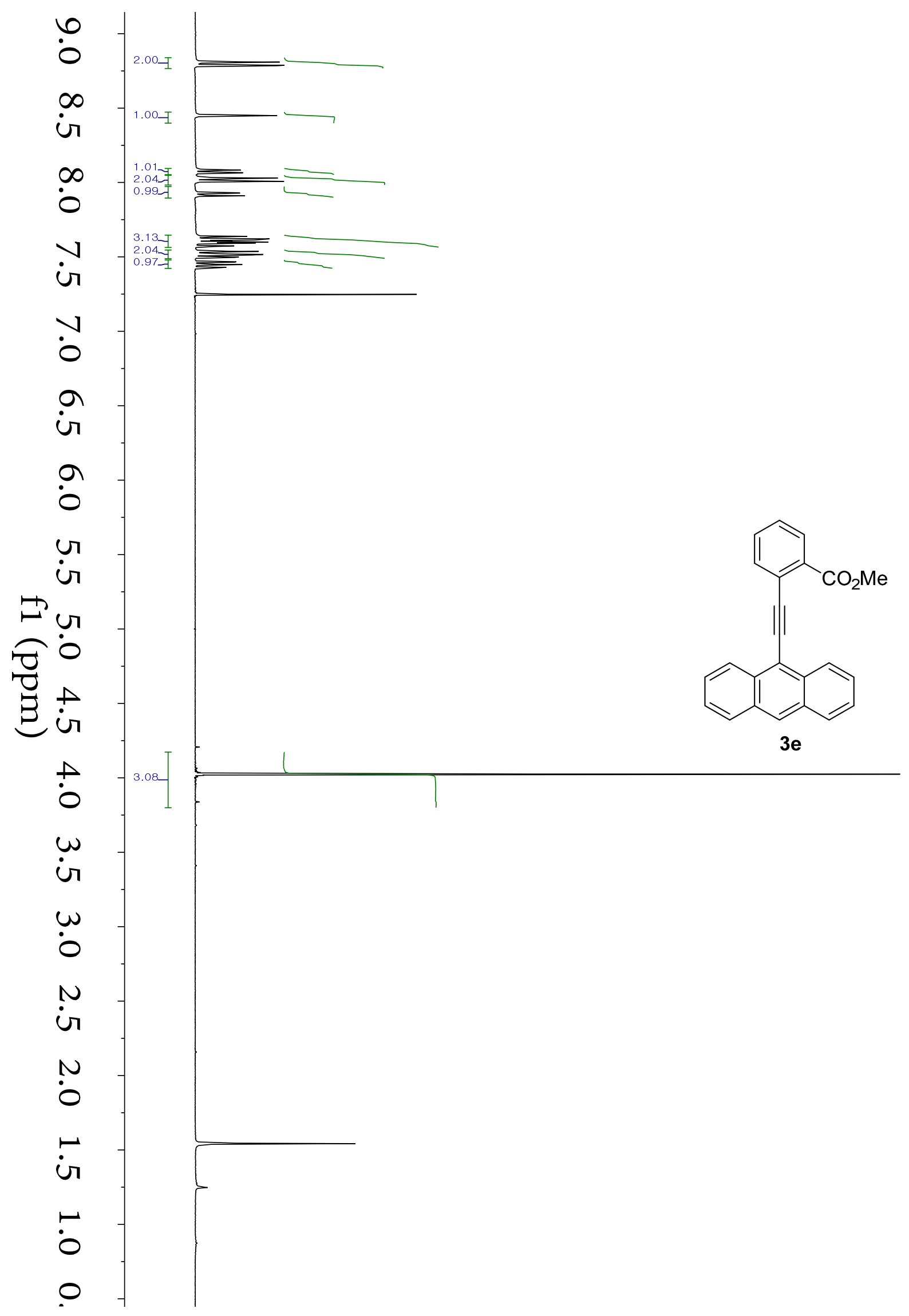

Figure S35. ${ }^{1} \mathrm{H}$ NMR spectrum of $3 \mathbf{e}$ recorded in $\mathrm{CDCl}_{3}$ at $25^{\circ} \mathrm{C}(400 \mathrm{MHz})$ 


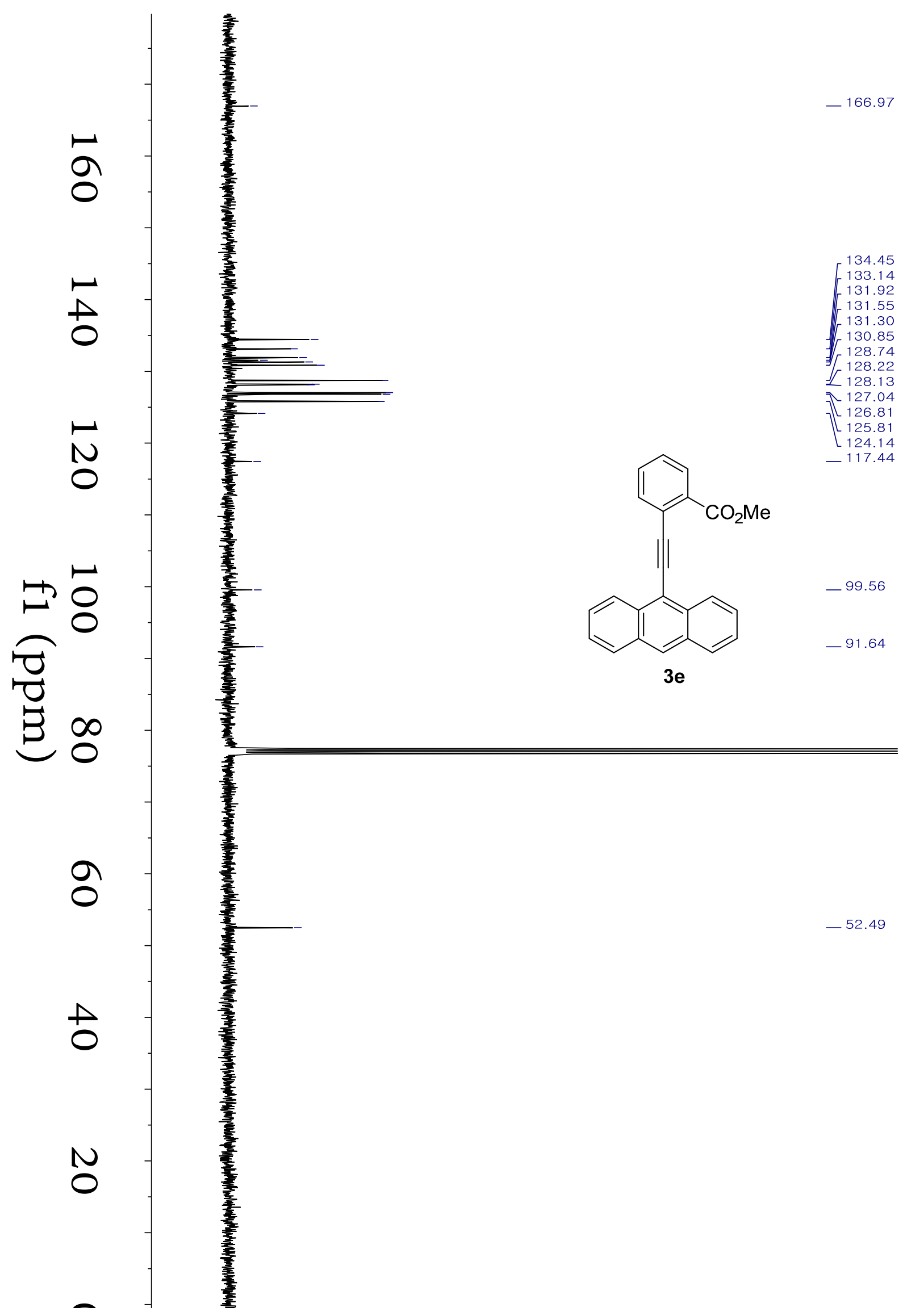

Figure S36. ${ }^{13} \mathrm{C}$ NMR spectrum of 3 e recorded in $\mathrm{CDCl}_{3}$ at $25^{\circ} \mathrm{C}(400 \mathrm{MHz})$ 


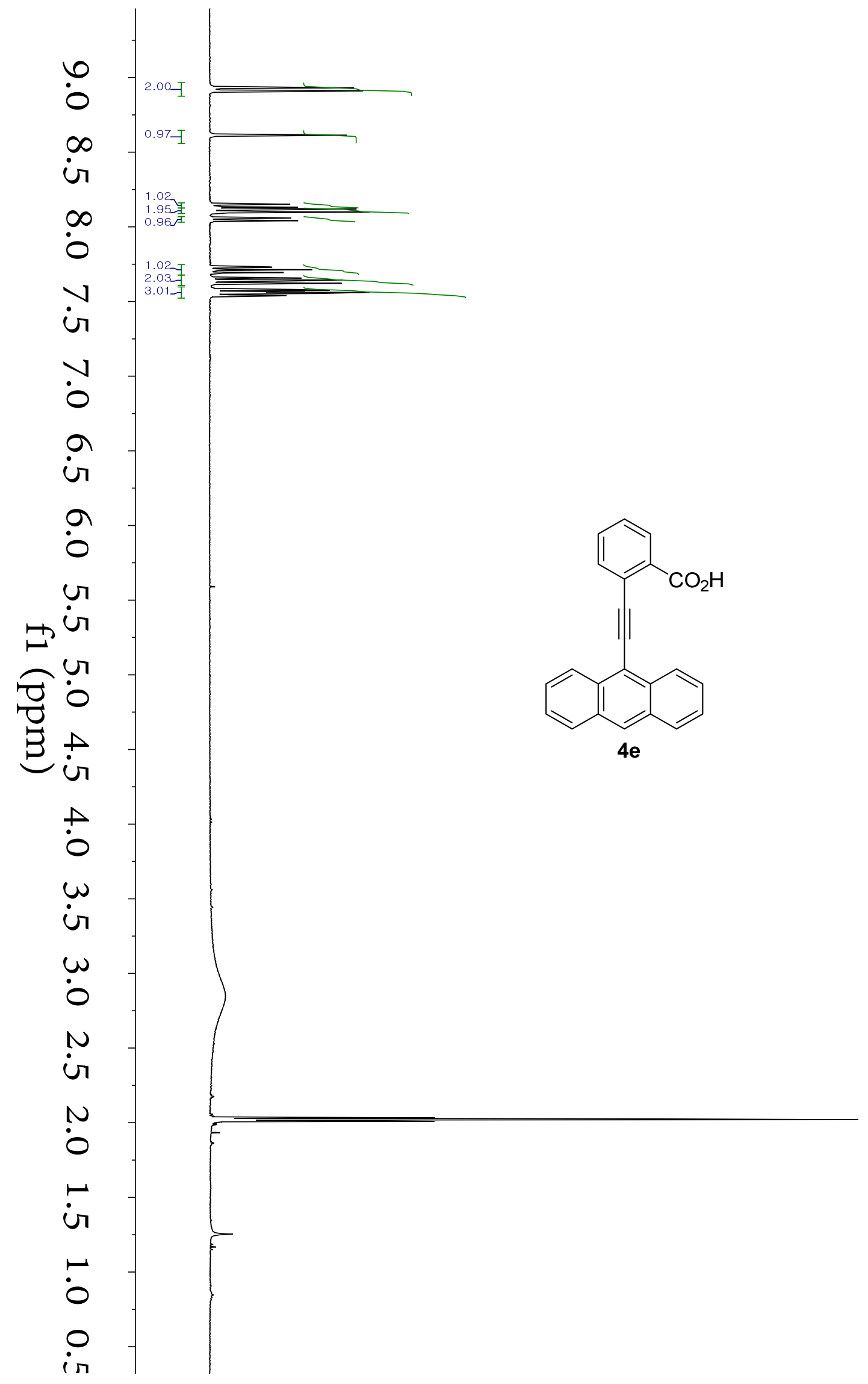

Figure S37. ${ }^{1} \mathrm{H}$ NMR spectrum of $4 \mathbf{e}$ recorded in acetone- $d_{6}$ at $25^{\circ} \mathrm{C}(400 \mathrm{MHz})$ 


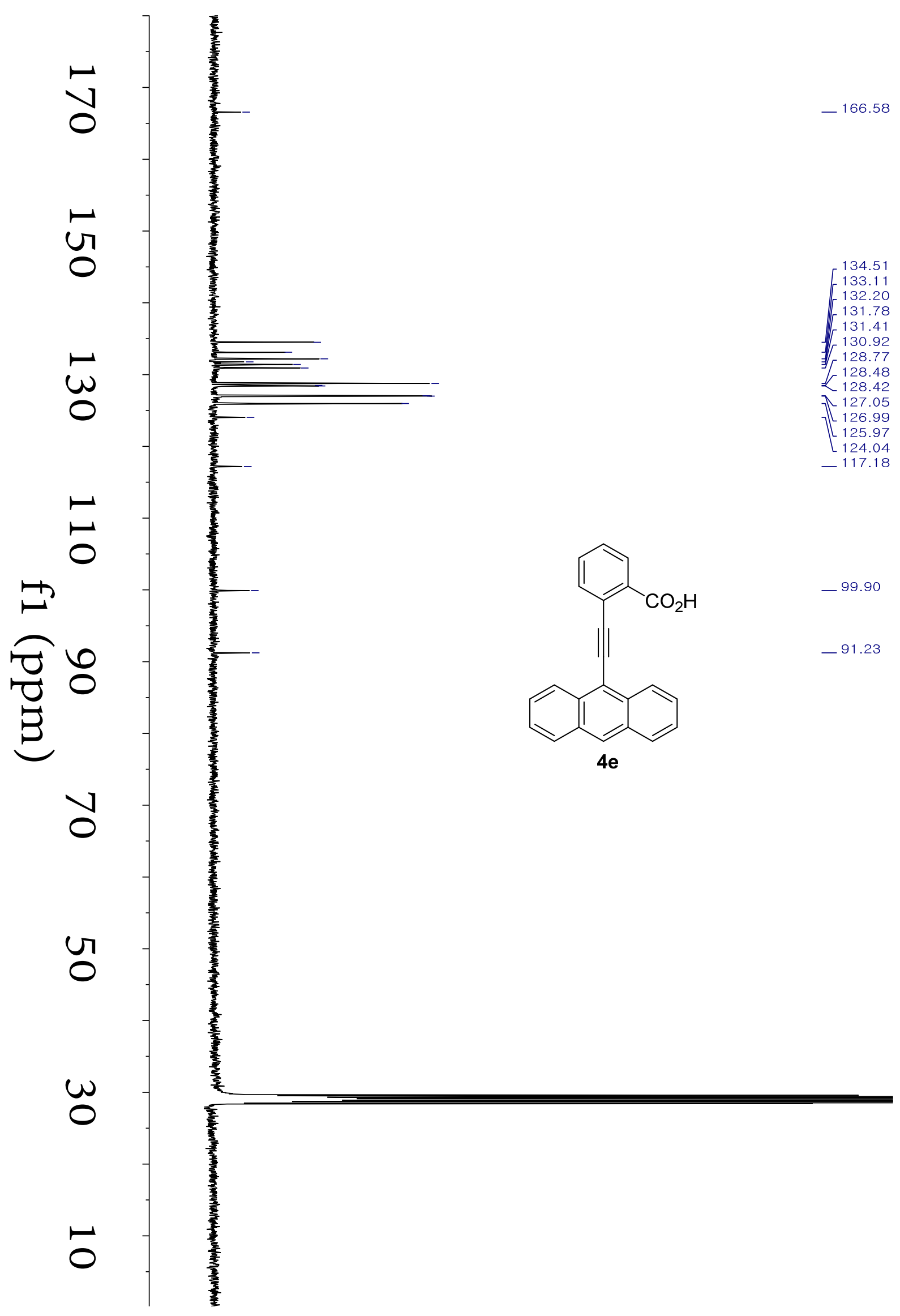

Figure S38. ${ }^{13} \mathrm{C}$ NMR spectrum of $4 \mathrm{e}$ recorded in acetone- $d_{6}$ at $25^{\circ} \mathrm{C}(400 \mathrm{MHz})$ 


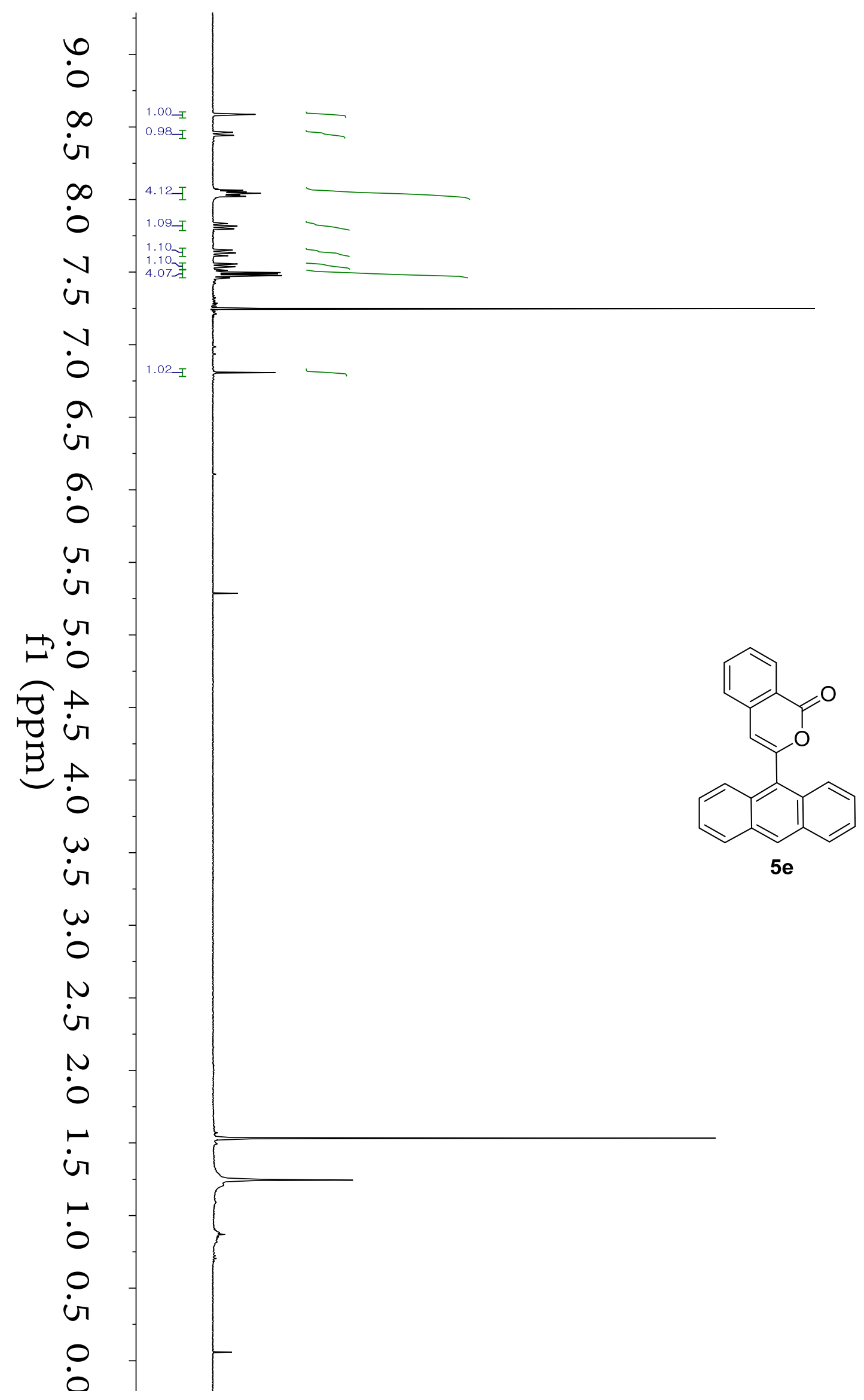

Figure S39. ${ }^{1} \mathrm{H}$ NMR spectrum of $5 \mathbf{e}$ recorded in $\mathrm{CDCl}_{3}$ at $25^{\circ} \mathrm{C}(400 \mathrm{MHz})$ 


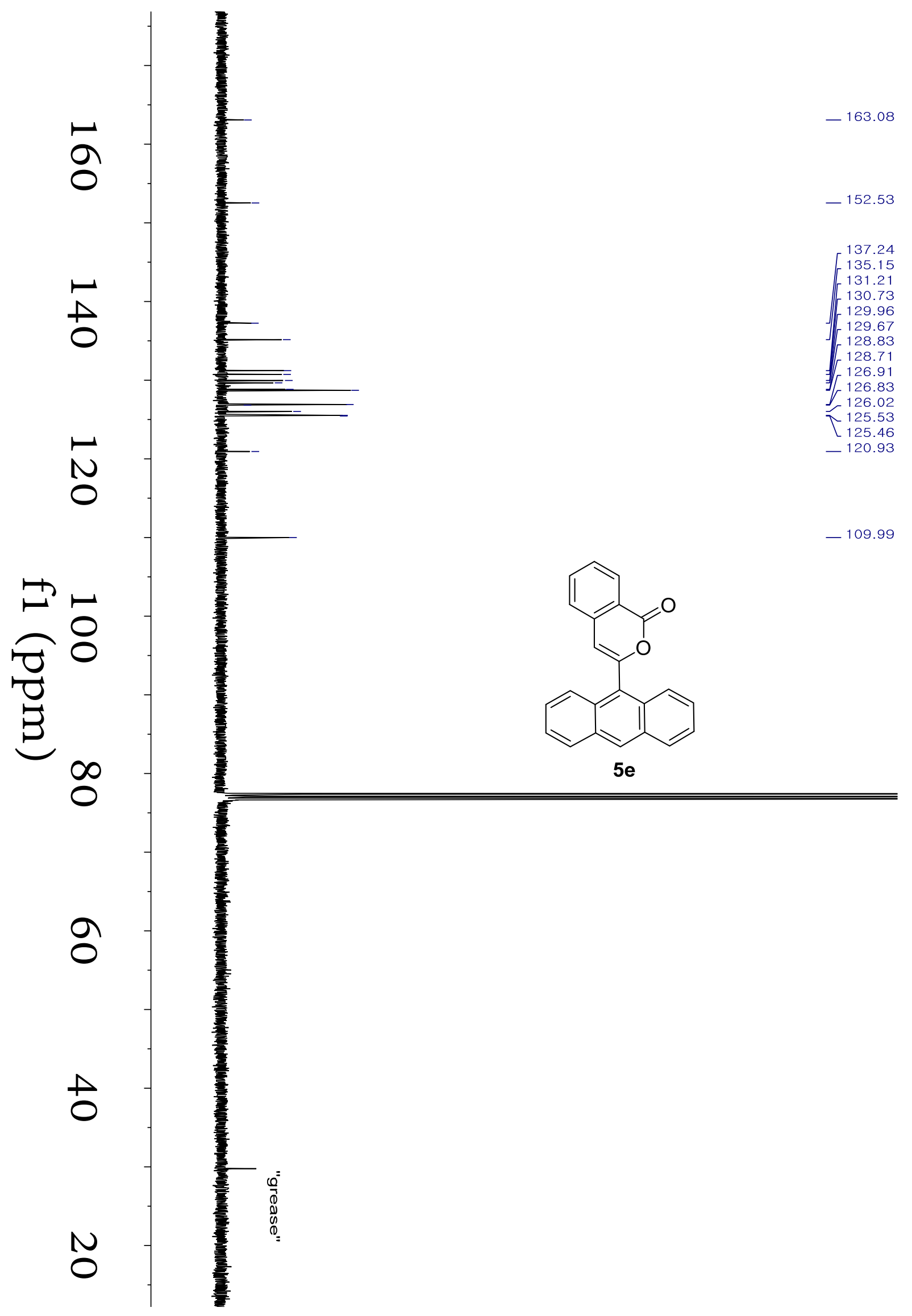

Figure S40. ${ }^{13} \mathrm{C}$ NMR spectrum of 5 e recorded in $\mathrm{CDCl}_{3}$ at $25^{\circ} \mathrm{C}(400 \mathrm{MHz})$ 